\title{
DOES BORDER ENFORCEMENT PROTECT U.S. WORKERS FROM ILLEGAL IMMIGRATION?
}

\author{
Gordon H. Hanson \\ Raymond Robertson \\ Antonio Spilimbergo \\ Working Paper 7054 \\ http://www.nber.org/papers/w7054 \\ NATIONAL BUREAU OF ECONOMIC RESEARCH \\ 1050 Massachusetts Avenue \\ Cambridge, MA 02138 \\ March 1999
}

We thank seminar participants at the University of Texas, Texas A\&M University, and the 1998 Midwest International Trade Meetings for comments. Hanson acknowledges financial support from the National Science Foundation (SBR-9617578) and the Russell Sage Foundation. The views expressed in this paper are those of the authors and do not reflect those of the National Bureau of Economic Research.

0 1999 by Gordon H. Hanson, Raymond Robertson, and Antonio Spilimbergo. All rights reserved. Short sections of text, not to exceed two paragraphs, may be quoted without explicit permission provided that full credit, including ${ }^{\circ}$ notice, is given to the source. 
Does Border Enforcement Protect U.S.

Workers from Illegal Immigration?

Gordon H. Hanson, Raymond Robertson, and Antonio Spilimbergo

NBER Working Paper No. 7054

March 1999

JEL No. D20, F10

\section{ABSTRACT}

In this paper, we examine the impact of government enforcement of the U.S.-Mexican border on wages in the border regions of the United States and Mexico. The U.S. Border Patrol polices U.S. boundaries, seeking to apprehend any individual attempting to enter the United States illegally. These efforts are concentrated on the Mexican border, as most illegal immigrants embark from a Mexican border city and choose a U.S. border state as their final destination. We examine labor markets in southern California, southwestern Texas, and Mexican cities on the U.S.-Mexico border. For each region, we have high-frequency time-series data on wages and on the number of person hours that the U.S. Border Patrol spends policing border areas. For a range of empirical specifications and definitions of regional labor markets, we find little impact of border enforcement on wages in U.S. border cities and a moderate negative impact of border enforcement on wages in Mexican border cities. These findings are consistent with two hypothesis: (1) border enforcement has a minimal impact on illegal immigration, or (2) immigration from Mexico has a minimal impact on wages in U.S. border cities.

Gordon H. Hanson

Department of Economics

University of Michigan

Ann Arbor, MI 48109-1220

and NBER

gohanson@umich.edu

Antonio Spilimbergo

Research Department

International Monetary Fund

700 19th Street, NW 20431
Raymond Robertson

Department of Economics

Syracuse University

Syracuse, NY 13244-2130

rarobert@syr.edu 


\section{Introduction}

A central component of U.S. immigration policy is the control of national borders. The U.S. Border Patrol polices international boundaries, seeking to apprehend any individual attempting to enter the United States illegally. These efforts are concentrated on the Mexican border, where most attempts at illegal entry occur. Recent events have intensified interest in undocumented immigration. Periodic economic downturns in Mexico contribute to surges in attempts at illegal entry (Hanson and Spilimbergo 1999), and there is a growing concern that immigrants are drawn to the United States by the availability of public assistance (Borjas and Hilton 1996). In response to these circumstances, the U.S. government has dramatically increased enforcement of U.S. borders. The number of hours Border Patrol officers spent policing the Mexican border rose from 1.8 million in 1977 to 5.1 million in 1997.

In this paper, we examine the impact of border enforcement on wages in border regions of the United States and Mexico. We study border areas as they are the regions most directly affected by illegal immigration. Most illegal immigrants embark from a Mexican border city and choose a U.S. border state as their final destination (Bustamante 1990; Warren 1995). Whatever the impact of illegal immigration, it is likely to be strongest in border labor markets. The regions we examine are southern California, southwestern Texas, and Mexican cities on the U.S.-Mexico border. For each of these regions, we have monthly (or quarterly) data on wages and on the number of person hours that the U.S. Border Patrol spends policing border areas and the number of apprehensions its officers make while on patrol. If border enforcement is effective at impeding illegal immigration from Mexico, then its effects, whether temporary or permanent, should be apparent in border communities. 
There is a small but growing literature on illegal immigration, to which we add. Hanson and Spilimbergo (1999), building on earlier papers by Bean et al. (1990) and Borjas, Freeman, and Lang (1991), find that illegal immigration from Mexico, as proxied by apprehensions at the U.S.-Mexico border, is highly responsive to changes in Mexican wages and, to a lesser extent, changes in U.S. wages. ${ }^{\prime}$ Related papers include case studies of Mexican communities that send illegal immigrants to the United States (Cornelius 1992; Donato, Durand, and Massey 1992), estimates of the undocumented population in the United States (Warren 1995), and estimates of the sensitivity of Mexican regions to U.S. labor-market shocks (Robertson 1998). ${ }^{2}$ There is very little work on whether border enforcement affects labor-market outcomes in the United States or Mexico. This gap in the literature is unfortunate, given the importance of border enforcement in U.S. efforts to control illegal immigration.

Our work also relates to a broader literature on whether immigration has lowered the wages of U.S. workers. ${ }^{3}$ This subject has attracted intense academic attention due to the coincidence of two events -- rising immigration of low-skilled individuals (Borjas 1994) and a relative decline in the earnings of low-skilled U.S. workers (Levy and Murnane 1992; Katz and Murphy 1992). The standard approach in the literature is to examine the correlation between changes in the wages of native U.S. workers and changes in the stock of immigrants in a cross section of U.S. metropolitan areas. ${ }^{4}$ The predominant finding is that immigration has, at most, a small negative effect on the earnings of native workers.

1 See Espenshade (1994) and Orrenius (1997) for related studies.

2 Durand and Massey (1992) and Espenshade (1995) review the literature on illegal immigration.

3 See Borjas (1994) and Friedberg and Hunt (1995) for surveys of this literature.

4 Grossman (1982) is an early contribution. Recent work includes Borjas (1987), Altonji and Card (1991), Lalonde and Topel (1991), Schoeni (1996), and Card (1997). Since the local stock of immigrants may be correlated with local labor-market shocks, most studies treat the stock of immigrants as an endogenous variable. 
There remains some doubt about whether existing research identifies the full effect of immigration on wages. Borjas, Freeman, and Katz $(1992,1997)$ find three problems with using cross-section data to identify the wage effects of immigration. First, wage growth varies across regions for reasons that are unrelated to immigration. Regions that, for whatever reason, attract immigrants may have exceptional wage growth over certain periods. Without exogenous controls for other factors that contribute to regional wage growth, the cross-sectional correlation between changes in immigration and wages may be uninformative. Second, native workers may respond to an influx of immigrants in their locale by migrating to other regions, mitigating the effect of immigration on local wages. The literature is divided about whether immigrant inflows contribute to native outmigration. Filer (1992) and Borjas, Freeman, and Katz (1997) find evidence that it does, while Card (1997) finds evidence that it does not. Third, regions may absorb immigrants without changes in wages by shifting into industries that use immigrant labor relatively intensively. In California, the arrival of immigrants from Mexico and other low-wage countries has been followed by rapid growth in apparel, textiles, food products, and other laborintensive industries (Hanson and Slaughter 1999).

Our approach helps assess the severity of the shortcomings in previous literature. Though our analysis of illegal immigration is indirect -- border enforcement influences the cost of entering the United States illegally, but it is not the sole determinant of illegal immigration -there are several important advantages to our approach. In contrast to existing studies, which mostly use cross-section data for U.S. regions at long time intervals, we have high-frequency time-series data on wages and border enforcement in regions on both sides of the U.S.-Mexico border. This allows us to control for the fact that long-run trends in wage growth may vary 
across regions. It also means that we are able to examine both the short-run and long-run effects of border enforcement on wages, thus controlling for the possibility that the arrival of illegal immigrants in border regions may cause an outmigration of native workers or a change in the mix of production activities in local industry.

In section II we describe the data we use in the analysis, in section III we discuss the empirical specification, and in section IV we present results. For a range of specifications and definitions of regional labor markets, we find only a weak positive correlation between border enforcement and wages in U.S. border regions and a moderate negative correlation between border enforcement and wages in Mexican border cities. These findings are consistent with two hypotheses: (1) border enforcement has a minimal deterrent effect on illegal immigration, or (2) illegal immigration from Mexico has a minimal impact on wages in U.S. border areas. We discuss interpretation of the findings in section V, by way of conclusion.

\section{Data}

As motivation for our focus on border labor markets, we briefly describe the spatial distribution of legal and illegal Mexican immigrants in the United States. To examine the impact of border enforcement on the U.S.-Mexico border region, we use a combination of industry data and survey data to construct time series of wages in U.S. and Mexican border regions.

\section{A. Border Labor Markets: Immigration and Enforcement}

Mexican immigrants in the United States tend to congregate in regions near the U.S.Mexico border. Data from the 1990 U.S. Census of Population and Housing (1\% PUMS) show 
that $46.5 \%$ of Mexican-born individuals that had immigrated within the previous five years resided in the border region of California and $8.6 \%$ resided in the border region of Texas. ${ }^{5}$ Of all Mexican immigrants, $41.6 \%$ resided in the California border region and $13.1 \%$ resided in the Texas border region. ${ }^{6}$ The immediate labor-market consequences of Mexican immigration are thus likely to be concentrated in border areas.

Recent Mexican immigrants tend to have low levels of education relative to U.S. workers. In 1990 Mexican-born individuals in the United States who had immigrated within the previous five years had an average of 9 years of education, compared to more than 13 years for U.S. natives. Unsurprisingly, workers who are recent immigrants are most prevalent in industries that are relatively intensive in the use of less-skilled labor. Table 1 shows the share of workers who are Mexican immigrants for selected industries in California, Texas, and the rest of the United States in 1980 and 1990 . We focus on manufacturing, as it is this sector for which we have wage data, but we also show figures for other high-immigrant industries. For the border region of California in 1990 , over $33 \%$ of workers in the apparel, textile, food products, lumber, and furniture industries were Mexican immigrants, and a substantial fraction of these were recent arrivals. In the state as a whole, the shares of workers who are Mexican immigrants are somewhat smaller. For the border region of Texas in 1990, the fraction of workers who were Mexican immigrants was $46 \%$ in apparel, $28 \%$ in textiles, and $22 \%$ in food products (and less in lumber and furniture). Again, immigrant shares in the state as a whole are smaller. In

\footnotetext{
5 We define the California border region to include the Anaheim-Santa Ana, Los Angeles-Long Beach, Riverside-San Bernadino, and San Diego MSAs, and the Texas border region to include the Austin, BrownsvilleHarlingen, Corpus Cristi, El Paso, Houston, McAllen-Edinburg, and San Antonio MSAs.

6 In 1980, 45.6\% (40.3\%) of recently arrived (total) Mexican immigrants resided in the California border region and $11.9 \%(14.3 \%)$ resided in the Texas border region.
} 
contrast to border states, Mexican immigrants account for a very small fraction of workers in these industries for the rest of the United States.

Recent Mexican immigrants include both legal and illegal aliens. Over the period 19801995, legal admissions of Mexican nationals by the U.S. Immigration and Naturalization Service (INS) averaged 62,600 individuals per year. ${ }^{7}$ Warren (1995) estimates that over the period $1982-$ 1992 the average annual net inflow of illegal Mexican immigrants was 158,600 individuals per year. Given the legal predicament of undocumented immigrants, we expect these individuals to be even more concentrated in U.S. border cities than legal immigrants. Nearly all illegal Mexican immigrants enter the United States by crossing the U.S.-Mexico border over land, which requires them to spend at least some time in a U.S. border region. Relatively large populations of Mexican nationals in U.S. border cities may make these areas relatively attractive for undocumented arrivals. Warren (1995) estimates that in $199259.5 \%$ of undocumented Mexican immigrants in the United States resided in California and $17.2 \%$ resided in Texas.

Illegal attempts to enter the United States are concentrated along the U.S.-Mexico border. Available data are from unpublished records of the INS, which contain monthly figures for 19771997 on the number individuals apprehended attempting to cross the U.S-Mexico border illegally and the number of person hours the U.S. Border Patrol spends policing the border. ${ }^{8}$ Both series

7 This figure excludes individuals admitted under the Immigration Reform and Control Act of 1986, which gave legal status to large numbers of long-term illegal aliens.

8 Data on enforcement and apprehensions are based on the "linewatch" activities of the U.S. Border Patrol. These activities occur at international borders; other enforcement activities, such as traffic checkpoints or raids on businesses, occur in the U.S. interior. Individuals apprehended by Border Patrol officers on linewatch duty are foreign residents attempting to enter the United States illegally; individuals apprehended by officers on nonlinewatch duty have been residing in the United States for an unknown period of time. For most of our work, we use data on linewatch enforcement, since this measure captures enforcement efforts targeted at new illegal immigrants. To check the sensitivity of our empirical results to this choice, we re-estimate all specifications replacing linewatch enforcement with total enforcement (linewatch plus non-linewatch). 
are broken down by nine geographic regions. ${ }^{9}$ Apprehensions are an indirect indication of attempted illegal immigration from Mexico. Over the sample period, more than $95.0 \%$ of those apprehended by U.S. Border Patrol were Mexican nationals, and over $99.0 \%$ of apprehensions by the U.S. Border Patrol occurred at the U.S.-Mexico border (INS 1996).

Figure 1 shows border apprehensions by state over the sample period. There is a seasonal pattern in apprehensions (high in the summer, low in the winter), which mirrors seasonal variation in U.S. labor demand (Hanson and Spilimbergo 1999). Most apprehensions occur in California; San Diego alone accounts for an average of $49.5 \%$ of all border apprehensions. El Paso is the second most important site for apprehensions, accounting for an average of $18.2 \%$ of apprehensions. These two locations are near large U.S. population centers and cites where the U.S.-Mexico border is relatively easy to cross. Late in the period, apprehensions rise in Arizona, following increased enforcement of the border in California which may have encouraged those attempting illegal entry to move east.

Figure 2 shows monthly border enforcement hours by U.S. border state over the sample period. In contrast to apprehensions, enforcement shows no seasonal pattern and is spread more evenly across regions. San Diego accounts for an average of $28.1 \%$ of enforcement hours and El Paso accounts for an average of $16.0 \%$ of enforcement hours. There are differences in the time path of enforcement across locations, which reflects regional variation in enforcement strategies. All locations show a rise and then fall in enforcement surrounding the implementation of the Immigration Reform and Control Act (IRCA) of 1986, which mandated an increase in expenditure on border enforcement. There is a sudden rise in enforcement in Texas in early

\footnotetext{
9 The regions, in order from west to east, are San Diego and El Centro (Califomia); Yuma and Tucson (Arizona); and El Paso, Marfa, Del Rio, Laredo, and McAllen (Texas).
} 
1993. This increase is due mainly to "Operation Hold the Line" in El Paso, during which enforcement hours more than doubled in a three-month period. Following this increase, enforcement hours in Texas decline somewhat over the next three years. Enforcement hours are stable in California between 1988 and 1993 and then rise dramatically in 1994 and 1995, as attempted illegal entry increased following a currency crisis and a severe recession in Mexico and as the INS increased border patrols in San Diego as part of "Operation Gatekeeper."

\section{B. Wages in U.S. and Mexican Border Regions}

We use several data sources to measure wages in the United States and Mexico. The concentration of immigrants in border regions and in specific industries suggests that the impact of immigration, and hence the impact of border enforcement, will be strongest in these regions and industries. To allow the short-run effects of border enforcement to differ from the long-run effects, it is important to use high-frequency data. It is also important to adjust for variation in worker characteristics, such as age and education, across regions and industries, which requires household-level data. Unfortunately, no data set has high-frequency observations on households with sample sizes that are large enough to allow disaggregation by education level, region, and industry. We use household-level data to measure wages by education level and region and industry-level data to measure wages by industry and region. Though neither data set is ideal, we aim to eliminate the possibility that our findings are an artifact of a particular data set by using as many different wage measures as possible.

For data on wages in high-immigrant industries in California and Texas, we use the Current Employment Statistics Survey from the Bureau of Labor Statistics (BLS), which gives 
the average hourly wage for production workers in selected industries and regions at a monthly frequency. As production workers tend to have much lower education and pay levels than nonproduction workers, they are the workers most vulnerable to competition from illegal immigrants and hence the workers most likely to benefit from border enforcement. We examine the apparel, textiles, food products, lumber, and furniture industries in California and Texas over the period 1977-1997. While data are available for individual cities within these states, gaps in BLS data collection for individual MSAs make the available city-level time series very short. For California, most employment in high-immigrant industries occurs in the Los Angeles area, so that California employment is a reasonable proxy for employment in Los Angeles. ${ }^{10}$ We confirm that our results hold for industries in individual MSAs over given subperiods.

For data on wages in U.S. border regions by education group, we use monthly data from the Current Population Survey (CPS), which covers approximately 60,000 households nationwide. The CPS identifies the state of residence for all households and the city of residence for all households in a metropolitan statistical area (MSA). For the border region of California, we include households in the Anaheim-Santa Ana, Los Angeles-Long Beach, Riverside-San Bernadino, and San Diego MSAs; for the border region of Texas, we include households in the Austin, Brownsville-Harlingen, Corpus Cristi, El Paso, Houston, McAllen-Edinburg, and San Antonio MSAs. While it might be preferable to examine wage movements in each city separately, small sample sizes for individual MSAs require us to aggregate across border cities within a state." Data are available for the period January, 1986 to May, $1995 .^{12}$

10 Over the sample period, the share of Califomia employment in the Los Angeles-Long Beach MSA is $72 \%$ in the apparel industry, $66 \%$ in the textile industry, $63 \%$ in the furniture industry, $28 \%$ in the food products industry, and $19 \%$ in the lumber industry.

11 In 1990 the share of Mexican-born individuals in the population varies in California from $7.6 \%$ in $S a n$ Diego to $13.5 \%$ in Los Angeles-Long Beach, and in Texas from $2.7 \%$ in Austin to $25.8 \%$ in McAllen. 
For data on wages in Mexican border regions, we use quarterly data from the Mexican National Urban Employment Survey (ENEU), which covers approximately 96,000 households in eight major urban areas. Included in the sample are Mexico's two largest border cities, Ciudad Juarez, which neighbors El Paso, and Tijuana, which neighbors San Diego, both of which are major crossing points for illegal immigrants. Data are available for the period 1987-1997.

Given the relatively low education levels of recent immigrants, the effects of immigration are likely to differ across skill groups for workers in both the United States and Mexico. To control for this possibility, we follow recent literature (see note 4) by calculating the age-adjusted mean wage for four education categories in each border region, in each time period. To do so, we estimate the following regression separately for each time period:

$$
w_{h t}=\sum_{i=2}^{T} \beta_{i t} D_{h i t}+\sum_{j=1}^{J} \sum_{k=1}^{K} \gamma_{j k t} E_{h j k t}+\epsilon_{h t}
$$

where $w_{h t}$ is $\log$ real earnings for individual $h$ in period $t, D_{h i t}$ is a dummy variable for whether individual $h$ belongs to age group $i, E_{h j k t}$ is a dummy variable for whether individual $h$ has education level $j$ and resides in region $k$, the $\beta_{i t}$ 's and the $\gamma_{j k i}$ 's are parameters to be estimated, and $\varepsilon_{h t}$ is an i.i.d. error term. ${ }^{13}$ The $\gamma_{j k}$ 's are age-adjusted mean wages for different education groups in different regions, which we use as dependent variables in subsequent analysis.

For both the CPS and the ENEU, the individuals included in the sample are non-selfemployed, non-military males aged 16-64 who worked at least twenty hours in the survey week.

12 Monthly CPS data are available for the period January, 1979 to December, 1996. Due to changes in classification codes for MSAs, there are no MSA identifiers in the data for the periods July-December, 1985 or June-August, 1995. In order to use a continuous time series, we are limited to the intervening period. State identifiers exist in CPS data for all months. We use both samples in our analysis.

${ }^{13}$ For CPS data, the wage is usual weekly earnings, deflated by the U.S. CPI for the current month; for ENEU data, the wage is usual monthly earnings, deflated by the Mexican CPI for the current month. 
We include dummy variables for five age groups, 16-24 years, 25-34 years, 35-44 years, 45-54 years, and 55-64 years. For CPS data, we estimate region-education dummy variables for five regions, border cities in California, non-border areas in California, border cities in Texas, nonborder areas in Texas, and the rest of the United States, and four education categories, highschool dropout, high-school graduate, some college, and college graduate. For ENEU data, we estimate region-education dummy variables for four regions, Ciudad Juarez, Tijuana, other border cities, and interior cities, ${ }^{14}$ and four education categories, 0-6 years (primary), 7-11 years (secondary), 12-15 years, and greater than 15 years. ${ }^{15}$

Figures 3 and 4 show average hourly wages for high-immigrant industries in California and Texas, relative to wages for the same industries in the United States as a whole. ${ }^{16}$ While real wages decline in all of these industries, there are also relative wage declines in California textiles and lumber and Texas food products. Figures 5 and 6 show age-adjusted mean wages of highschool dropouts and high-school graduates in California and Texas border cities, relative to those for the corresponding education group in the rest of the United States. Wages for both highschool dropouts and high-school graduates in California tend to be higher than in the rest of the nation, but they decline in relative terms over the period. Wages for both education groups in Texas are below those for the rest of the nation, and, though highly variable, show no time trend. Figure 7 shows age-adjusted mean wages for individuals with primary (0-6 years) education and secondary (7-11 years) education for Ciudad Juarez and Tijuana; wages are relative to those for

\footnotetext{
14 The other border cities are Matamoros and Nuevo Laredo. The interior cities are the country's three largest cities, Guadalajara, Mexico City, and Monterrey.

15 The education categories for Mexico group individuals with similar skill levels, as indicated by average earnings. There are spikes in the distribution of schooling at 6 years (primary school), 9 years (secondary school), and 12 years (preparatory school). Very few individuals complete 16 or more years of schooling.

16 Given age-adjusted mean wages are estimated coefficients from log-wage regressions, the relative wages we show in Figures 3-6 are the log difference of the two relevant series.
} 
the corresponding education group in interior Mexican cities. Wages are high relative to interior cities, particularly in Tijuana, but decline over the period.

\section{Empirical Specification}

\section{A. Empirical Model}

In this section, we present an empirical specification for how border enforcement will influence and be influenced by wages in border regions. The starting point for the analysis is the idea that wages in border regions will be affected by three factors: the migration of labor between regions within a country, the immigration (or emigration) of labor from neighboring countries, and local labor demand conditions. Rather than derive a structural model of wage determination, we use a vector autogression (VAR) to summarize the manner in which border wages, border enforcement, and wages in surrounding regions are jointly determined.

We assume workers prefer to be in the region that pays the highest real wage. If shocks to labor demand or labor supply lower wages in the border region relative to the country as a whole, workers will migrate away from the region until regional wages are equalized. Moving costs or other frictions between regional labor markets may create dynamics in the adjustment process (Topel 1986, Blanchard and Katz 1992). Labor migration between regions within a country suggests that wages in border areas will be influenced by wages in surrounding regions.

Wages in U.S. border regions will also be influenced by the immigration of workers from Mexico, where we focus on illegal immigration. ${ }^{17}$ Attempted illegal immigration will be higher,

\footnotetext{
17 While it would be desirable to also examine legal immigration, we lack high-frequency data on the stock of legal immigrants in border areas. It is important to note, however, that many legal immigrants may choose to immigrate illegally while they await the outcome of their application for legal immigration. Until 1998, there were no potential legal consequences of doing so (Hanson and Spilimbergo 1999).
} 
the higher is the real U.S. wage relative to the real Mexican wage. The responsiveness of illegal immigration to U.S.-Mexico wage differentials will depend on the costs of crossing the border, an important component of which is the possibility of apprehension by the U.S. Border Patrol and deportation back to Mexico. Once apprehended, individuals lose time out of the labor market and face other psychic and monetary costs associated with detention. For a given U.S.Mexico relative wage, higher levels of enforcement by the U.S. Border Patrol will presumably reduce attempts to enter the United States illegally, which will in turn affect wages along the border. Through its impact on the flow of illegal immigrants across the U.S.-Mexico border, we expect increases in border enforcement to put upward pressure on wages in U.S. border regions and downward pressure on wages in Mexican border regions. ${ }^{18}$

Border enforcement may in turn be influenced by labor-market conditions in the United States and Mexico. If the U.S. Border Patrol chooses how intensively to enforce the border based on expected illegal attempts to cross the border, then border enforcement is likely to be increasing in the U.S.-Mexico wage differential. Factors other than labor-market conditions may also influence border enforcement. U.S. politicians periodically campaign for more enforcement of U.S. borders to gain the support of constituents that, for real or imagined reasons, feel threatened by illegal immigration. This suggests that border enforcement may follow political cycles, which may or may not be correlated with economic cycles.

The relationship between border wages, border enforcement, and wages in surrounding regions may be summarized by the following bivariate VAR:

\footnotetext{
18 Border enforcement may reduce the inflow of illegal immigrants either directly, by leading to the apprehension and deportation of those that attempt illegal immigration, or indirectly, by deterring individuals in Mexico from attempting to enter the United States illegally. In either case, border enforcement puts upward pressure on wages in U.S. border regions and downward pressure on wages in Mexican border regions.
} 


$$
y_{t}=\alpha+\sum_{i=1}^{s} \beta_{i} w_{t-i}+\sum_{i=1}^{s} \delta_{i} h_{t-i}+\sum_{i=1}^{S} \gamma_{i} X_{t-i}+\rho t+\mu_{t}
$$

where $y_{t}$ is a $2 \times 1$ vector consisting of $w_{b}$, the wage in the U.S. border region, and $h_{t}$, U.S. border enforcement (person hours the U.S. Border Patrol spends policing the border); $X_{t}$ is a $\mathrm{kx} 2$ vector of other variables that influence border wages, including wages in the rest of the United States and wages in Mexico; $\alpha, \rho$, and the $\beta_{i}$ 's and $\delta_{i}$ 's are $2 \times 1$ vectors of parameters; the $\gamma_{i}$ 's are $2 x k$ matrices of parameters; $\mu_{1}$ is a $2 \times 1$ vector of i.i.d. error terms; and all variables are in logs. The time trend captures trend growth in border wages. For the United States, the border regions we examine are those in California and Texas. The border wage may be that for a particular skill group (high-school dropouts, high-school graduates) or for a particular industry (apparel, food processing, textiles, lumber, furniture).

In an analogous manner, wages in Mexican border regions are likely to be influenced by wages elsewhere in Mexico, wages in the United States, and enforcement of the U.S.-Mexico border. Border enforcement conditions the probability of successful emigration from Mexico. As Mexican border regions are the point of departure for illegal emigration to the United States, the short-run and long-run supply of labor in these regions is likely to be affected by changes in the intensity of border enforcement (though perhaps in quite different ways). We also estimate a dynamic specification of wages in Mexican border cities, similar to that in equation (2). 


\section{B. Estimation Issues}

There are several estimation issues to be addressed. A first issue is that in equation (2) we implicitly assume that the variables in the $X_{t}$ vector are exogenous to wages in the U.S. border region and to border enforcement. These variables include wages in non-border regions of the United States, national wages in Mexico, and, in unreported results, unemployment rates in U.S. border states. To verify that this assumption of exogeneity is warranted, we perform tests of block exogeneity for these variables (Hamilton 1994), in which we test the null hypothesis that lagged values of border wages and border enforcement are uncorrelated with the elements of the $X_{t}$ vector (where lagged values of this vector are included as explanatory variables). For all measures of border wages, we fail to reject the null at any reasonable level of significance. This justifies our assumption that equation (2) is a bivariate VAR containing additional exogenous explanatory variables.

A second estimation issue is that illegal immigration may create a spurious correlation between border enforcement and wages in U.S. border regions. To the extent that illegal immigrants earn lower wages that residents of the United States, their entry into the U.S. labor force will by definition lower measured average wages in the United States, even if they have no impact on the wages of existing U.S. residents. If lower levels of border enforcement allow higher levels of illegal immigration, there may be a spurious positive correlation between U.S. wages and border enforcement. While such compositional effects are likely to be small in highfrequency data, we still control for this problem by excluding potential illegal immigrants from the sample. In estimating equation (2) on CPS data, we exclude from the sample all individuals 
that describe themselves as born in Mexico and not U.S. citizens. ${ }^{19}$ While this unfortunately eliminates long-term Mexican residents, both legal and illegal, from our data, it ensures that our data are unpolluted by compositional effects. We are unable to control for compositional effects in BLS industry wage data. Thus, OLS coefficients on lagged border enforcement in industry wage regressions may suffer from positive bias.

A third estimation issue arises from the fact that for some specifications (those relying on wage data from the CPS or ENEU) we measure wages using coefficient estimates from the regression in equation (1). These coefficient estimates appear as dependent variables in equation (2). By construction the disturbance term in equation (2) will include a sampling error that has a nonconstant variance over time. We use the White (1980) estimator to obtain heteroskedasticity-consistent standard errors. A further problem is that equation (2) also includes lagged values of the dependent variables as regressors. By using constructed regressors, we may be introducing measurement error into the estimation. One solution would be to use instrumental variables. Valid instruments, in this case, are extremely difficult to find, since we need variables that are correlated with the first several lags of wages but uncorrelated with contemporaneous shocks to wages (at monthly frequencies). ${ }^{20}$ We address the errors-in-variables problem indirectly by examining the sensitivity of our results to changing the measure of wages that is used. Some

\footnotetext{
19 We exclude individuals who define themselves as "Mexicanos" from the sample. The CPS uses three categories for persons of Mexican descent, Mexican-American, Chicano, and Mexicano. The BLS includes these as "write-in" categories and thus does not maintain strict definitions. Nonetheless, Mexican-Americans are generally believed to be U.S. citizens of Mexican descent, Chicano is an alternative term for U.S. citizens of Mexican decent used mostly by the cohort of individuals who were young adults in the 1970s, and Mexicano appears to be used mostly by Mexican-bom individuals who are not U.S. citizens.

20 An alternative approach would be to use the variance of the estimated coefficients from the first-stage regression in equation (1) as an estimate of the variance on the measurement error on the generated regressors in the second-stage estimation of equation (2), which is similar to orthogonal regression. In unreported results, we applied such regression techniques to CPS data. Since the coefficient estimates we obtained were implausible (negative values for coefficients on the lagged dependent variables), we do not report them here.
} 
specifications, notably those using industry average wages (from BLS data), are not subject to the same concerns about errors in the regressors.

\section{Empirical Results}

In this section, we examine the relationship between enforcement of the U.S.-Mexico border and wages in U.S. and Mexican border regions. Table 2 gives variable definitions and summary statistics for selected variables used in the analysis. For the United States, we examine wages in high-immigrant industries in California and Texas, and wages of male high-school dropouts and high-school graduates in California and Texas border cities; for Mexico, we examine wages for males with primary and secondary education in the two largest border cities.

One important issue for VAR estimation concerns choosing the correct lag length for the regressors. This is somewhat tricky in our case, since we have no independent information on how long it takes for increases in border enforcement today to impact labor markets in border areas. The impact is likely to be relatively rapid in Mexican border communities, since increases in border enforcement impede workers from leaving Mexico. On the U.S. side of the border, it is unclear how long it takes illegal immigrants to enter the labor force, once they have crossed the border. We choose the lag length indicated by the Schwarz Criterion. ${ }^{21}$

As an informal indication of the relationship between wages and enforcement, Figures 811 show cross-correlograms for border enforcement and each measure of border wages, where all series are detrended. These graphs plot the correlation between log border wages and leads and lags of log border enforcement. If enforcement does impact wages, we would expect to see

\footnotetext{
21 In most cases, the lag length indicated by the Schwarz Criterion is the same as that indicated by the Akaike Information Criterion.
} 
a positive correlation between wages and lags of enforcement in U.S. border regions and a negative correlation between wages and lags of enforcement in Mexican border regions. Without additional controls, however, these raw correlations are only a rough indication.

Figure 8 shows that in the California food products, apparel, and lumber industries there is a positive correlation between wages and border enforcement, which peaks at two to four lags of enforcement. This is weakly consistent with the hypothesis that border enforcement leads border wages. For Texas border industries, shown in Figure 9, there is a similar relationship between wages and enforcement in lumber and furniture. There is also a positive correlation between wages and enforcement in apparel, but it peaks for the contemporaneous correlation. There is zero correlation between wages and enforcement in food products and textiles. Turning to wages for high-school dropouts and high-school graduates in California and Texas border cities, shown in Figure 10, we see zero or negative correlations between wages and enforcement. Finally, Figure 11 shows cross-correlograms for Mexican border cities. There is a negative correlation between wages and enforcement in all cases, which peaks at six to eight leads of enforcement suggesting that wages lead enforcement rather than the reverse. Overall, the crosscorrelograms reveal no consistent relationship between wages and enforcement. The regression results we report below confirm this finding.

\section{A. High-Immigrant Industries in California and Texas}

Tables 3-6 report OLS regression results, using either U.S. industry wages or border enforcement as the dependent variable. Data are monthly and the time period is January, 1977 to June 1998. We examine whether border enforcement Granger causes wages in U.S. border 
industries and whether U.S. border wages Granger cause border enforcement. For each case, we report results with and without additional control variables in the estimation. The wage measure is the log of average hourly real wages for production workers in the food products, textiles, apparel, lumber, or furniture industries in California or Texas. The measure of border enforcement is the log of total enforcement hours in Border Patrol sectors along either the California or Texas-Mexico border. The additional control variables are log wages for the U.S. industry as a whole and log real average hourly wages for manufacturing workers in Mexico. All regressions include monthly dummy variables, a time trend, and three lags on the regressors. Results for either two or four lags are very similar to those reported below.

To begin, consider the results in Table $3 \mathrm{a}$, in which wages are the dependent variable and there are no additional controls in the regression. In two industries, apparel and lumber, the coefficients on lagged border enforcement are jointly statistically significant at the $5 \%$ level, and in three industries, the previous two plus textiles, they are jointly significant at the $10 \%$ level. The results change markedly, however, when additional controls are included in the regression. In Table $3 b$, we add lagged national industry wages and Mexican wages to the set of regressors. The coefficients on lagged border enforcement are jointly significant at the $5 \%$ in only one industry, lumber. In all other industries we easily reject the null hypothesis that border enforcement Granger causes border wages.

Despite the imprecision of the coefficient estimates, it is important to ask whether the estimated impact of border enforcement on industry wages in California is economically important. Table 3 also reports the estimated long-run elasticity of wages with respect to border enforcement. In Table $3 \mathrm{~b}$, the long-run elasticity of California industry wages with respect to 
border enforcement ranges from 0.04 in apparel to 0.09 in lumber (ignoring the furniture industry, where the estimated impact ranges from positive to negative). This impact is small, especially when we consider that, given potential upward bias from compositional effects, it is likely to be an upper bound on the true long-run impact.

Table 4 reports results using the identical specification as in Table 3, except with border enforcement as the dependent variable. There is little evidence that wages in high-immigrant California industries influence border enforcement. In all regressions, except in the case of the lumber industry without additional controls in the regression (Table 4a), we fail to reject the null that the coefficients on lagged California industry wages are jointly zero at the $5 \%$ level. This is not to say, however, that economic conditions in the United States are irrelevant for the border enforcement decision. Unreported coefficient estimates indicate that for most industries, national U.S. industry wages have a positive and statistically significant long-run impact on border enforcement. This is consistent with the idea that the INS raises enforcement when economic conditions in the United States improve, making the United States more attractive to prospective immigrants in Mexico (but does not raise enforcement when economic conditions in U.S. border states improve relative to the country as a whole).

In Tables 5 and 6, we repeat the analysis for Texas. Here, the results are even weaker. Only in lumber are lagged values of border enforcement (along the Texas-Mexico border) jointly significantly correlated with Texas industry wages. The estimated long-run impact of enforcement on wages is again quite small. In no industry are lagged Texas industry wages jointly significantly correlated with border enforcement. For most industries, it is again the case that border enforcement along the Texas-Mexico border is positively correlated with lagged 
values of national U.S. industry wages. Taken with the previous results, it appears that the INS raises enforcement along the entire U.S.-Mexico border when overall economic conditions in the United States improve (but not when economic conditions improve in border states alone).

In unreported regressions, we examine the sensitivity of our results to alternative specifications and sample periods. We experiment with altering lag lengths on the regressors, using national in place of regional measures of border enforcement, replacing California industry wages with industry wages for the Los Angeles-Long Beach MSA (where Mexican immigrants are highly concentrated), dropping observations after the devaluation of the peso in 1994 (which was followed by a severe recession in Mexico), and adding apprehensions of individuals at the border as a regressor. None of these changes has a material impact on the results. Border enforcement has at most a weak positive impact on border industry wages and border industry wages have no impact on border enforcement.

\section{B. Califomia and Texas Bonder Cities}

In the preceding section, the unit of analysis was the average hourly wage for a highimmigrant industry in a border state. While the industries in question are those where illegal immigration seems most likely to have an observable impact, using average industry wages may smooth over variation across workers, making the impact of border enforcement on wages difficult to detect. In this section, we adopt an alternative definition of border labor markets. We examine low-education males in California and Texas border cities. We perform a similar series of regressions as those in Tables 3-6, except that now wages are the age-adjusted mean wage for either high-school dropouts or high-school graduates in a given region. All other 
variables, including border enforcement, remain the same. Data limitations restrict the analysis to monthly data for the period January, 1986 to May, 1995. Table 7 reports the results.

The first column of Table 7 shows results using the wage for high-school dropouts in California border cities as the dependent variable. We find a weak negative correlation between border wages and lagged border enforcement. The correlation between wages for high-school graduates and border enforcement, shown in column two, is also negative, though with less statistical significance. The results for Texas, shown in columns three and four, are similar. There is a negative correlation between wages and border enforcement for high-school dropouts, which is statistically significant, and an imprecisely estimated correlation between wages and border enforcement for high-school graduates. For neither California nor Texas do we find that increases in border enforcement contribute to higher wages for low-education males. In unreported results, we replaced border wages with border enforcement as the dependent variable. Similar to the results in the previous section, in no case is border enforcement jointly significantly correlated with lagged values of border wages.

To check the sensitivity of these results, we used alternative specifications and sample periods. The results are unaffected by changing lag lengths on the regressors, replacing regional border enforcement with national border enforcement, or including border apprehensions as a regressor. Finally, we performed similar regressions in which we used the age-adjusted mean wage for high-school dropouts or high-school graduates in either all of California or all of Texas as the dependent variable. The advantage of this approach is that we are able to extend the time period for the analysis to January, 1979 to March, 1996. We again find no evidence that border enforcement has a positive long-run impact on wages in border states (indeed, in most cases the 
estimated long-run impact of enforcement on wages remains weakly negative).

That we estimate a negative correlation between border wages and border enforcement using wages constructed from CPS data contrasts with the results in Tables 3-6, in which we use industry average wage data from the BLS. As indicated earlier, one concern is that measurement error in the constructed wage measures from CPS data may contaminate the regression results and somehow lead to downward bias in the estimated impact of enforcement on wages, in which case the results in Table 7 would underestimate the impact of enforcement on wages. It is important to re-emphasize that our concerns about compositional bias in average industry wages suggest that the results in Tables 3-6 may overestimate the impact of enforcement on wages. Taking either set of results, there is little evidence that border enforcement significantly raises wages in U.S. border regions or industries.

\section{Mexican Border Cities}

Although the effects of border enforcement are negligible in U.S. border regions, it is possible that U.S. border enforcement may have large effects on labor markets in Mexican border regions. Mexican border cities are the transit point for most undocumented Mexican immigrants and changes in border enforcement could have large effects, whether temporary or permanent, on local labor supplies in these areas. We examine the two largest Mexican border cities, which are also the major border crossing points for illegal immigrants, Tijuana, which neighbors San Diego, and Ciudad Juarez, which neighbors El Paso. The empirical specification is similar to that in previous sections. The dependent variable is the age-adjusted mean wage for Mexican males with either primary (0-6 years) or secondary (7-11 years) education. Enforcement is now 
measured as the log of monthly enforcement hours summed into quarters to match the frequency of the wage data. Additional control variables are the log U.S. average hourly real wage for production workers in manufacturing, the age-adjusted mean wage for the corresponding education group in interior Mexico, and a time trend. The data are quarterly and cover the period 1987:1 to $1997: 4$. Table 8 contains the results.

We find that U.S. border enforcement has a negative but often imprecisely estimated effect on Mexican wages. For Tijuana, lagged values of border enforcement are jointly significantly correlated with wages for males with either primary or secondary education. For Ciudad Juarez, there is no such evidence. The long-run elasticity of wages with respect to border enforcement is -0.30 for both education groups in Tijuana and -0.03 to -0.04 for the two education groups in Ciudad Juarez. Only for the secondary education group in Tijuana, however, is the long-run impact significant. Thus, the results for Tijuana suggest border enforcement has an economically significant impact on wages in the region, at least for males with secondary education. The size of the effect is greater than that found for any U.S. border area.

The findings for Tijuana and Ciudad Juarez are robust to alternative lag structures. The magnitude of the long-run effect for Tijuana increases somewhat when a third lag on the regressors is added. To further evaluate the robustness of the results, we included the real exchange rate as a regressor and examined results for other large Mexican border cities. Including the real exchange rate does not affect the results qualitatively. The other border cities we examine are Matamoros and Nuevo Laredo, which, over the sample period, were not primary points for illegal entry into the United States. Unsurprisingly, we find no significant effects of border enforcement on Mexican wages in either city. 
The results suggest that U.S. border enforcement has a moderate negative effect on Mexican wages. One problem is that the sample period, ten years with quarterly data, is short. This leaves open the possibility that the results we find for Tijuana might not hold for other time periods. Unfortunately, the data do not permit extending the analysis backwards in time.

\section{Discussion}

In this paper, we examine the correlation between enforcement of the U.S.-Mexico border and wages in U.S. and Mexican border regions. For high-immigrant industries in California and Texas, we find a positive long-run impact of border enforcement on wages for one industry only, lumber, and even in this case the magnitude on the impact is quite small. We find no positive effects whatsoever for low-education males in the border regions of either state. For Mexico, the impact of U.S. border enforcement is larger. We find a moderate negative impact of border enforcement on wages for males with secondary education in Tijuana, which is where a large fraction of attempts at illegal entry occur over the sample period.

Our results are consistent with two alternative hypotheses. One is that border enforcement has a minimal impact on illegal immigration. In this case, it would still be possible that illegal immigration puts downward pressure on wages in U.S. border regions, but, since border enforcement does not impede illegal immigration, we would find no correlation between enforcement and wages in U.S. border regions. We find this interpretation implausible. That wages in Tijuana decline following increases in border enforcement suggests that border enforcement does influence border labor markets, if only in Mexico and not the United States. Additionally, there is abundant evidence that when border enforcement increases at one part of 
the border, attempts at illegal entry, and hence apprehensions, increase along other parts of the border (see Figures 1 and 2). Substitution between border crossing sites indicates that at the margin prospective immigrants are deterred by higher levels of border enforcement. Graphic illustrations of this fact are in unfortunate abundance. Following recent increases in border enforcement at the traditional crossing points of San Diego, El Centro, and El Paso, more immigrants have attempted to enter the United States by crossing the Sonoran desert into Arizona. There has been a corresponding surge in deaths among those attempting illegal entry.

A second interpretation of our results is that border enforcement does deter illegal immigrants but that illegal immigration has a minimal impact on labor markets in U.S. border regions. We believe this to be the more defensible conclusion. There are two ways in which border regions may adjust to influxes of illegal immigrants without large changes in wages. The first is that, given an immigrant influx, U.S. natives may leave border regions or be deterred from moving to border regions. Filer (1992) and Borjas, Freeman, and Katz (1997) provide evidence in support of this view. The second is that border economies over time may shift towards industries that are relatively intensive in the use of the skills of arriving immigrants. Hanson and Slaughter (1999) find evidence in support of this view, especially for California.

Border enforcement remains the centerpiece of U.S. policy on illegal immigration. The costs and benefits of this strategy are currently the subject of intense debate. The results in this paper suggest that concerns about the wage impact of illegal immigration have been exaggerated. While our results do not imply that eliminating border enforcement would leave labor markets in U.S. border areas unaffected, over the range of values for which we observe variation in border enforcement we detect no benefits for U.S. border communities in terms of higher wages. 


\section{References}

Altonji, J.G. and D. Card. 1991. "The Effects of Immigration on the Labor Market Outcomes of Less-Skilled Natives." In J.M. Abowd and R.B. Freeman, eds., Immigration, Trade, and the Labor Market. Chicago: University of Chicago Press, pp. 201-59.

Bean, Frank D.; Espenshade, Thomas J.; White, Michael J. and Dymowski Robert F. "PostIRCA Changes in the Volume and Composition of Undocumented Migration to the United States: An Assessment Based on Apprehensions Data," in Frank D. Bean, Barry Edmonston, and Jeffrey S. Passel, eds., Undocumented migration to the United States: IRCA and the experience of the 1980's. Washington, DC: The Urban Institute, 1990, pp. 111-58.

Blanchard, O. and L. Katz. 1992. "Regional Evolutions." Brookings Popers on Economic Activity 1: 1-75.

Borjas, G.J. 1987. "Immigrants, Minorities, and Labor Market Competition." Industrial and Labor Relations Review 40: 382-392.

Borjas, George J. "The Economics of Immigration." Journal of Economic Literature, December 1994, 32(4), pp. 1667-1717.

Borjas, G.J., R.B. Freeman, and L.F. Katz. 1992. "On the Labor Market Effects of Immigration and Trade." In G.J. Borjas and R.B. Freeman, eds., Immigration and the Work Force. Chicago: University of Chicago Press, pp. 213-44.

Borjas, G.J., R.B. Freeman, and L.F. Katz. 1997. "How Much do Immigration and Trade Affect Labor Market Outcomes?" Brookings Papers on Economic Activity 1: 1-90.

Borjas, G.J., Freeman, Richard B. and Lang, Kevin. 1991. "Undocumented Mexican-Born Workers in the United States: How Many, How Permanent?" in John M. Abowd and Richard B. Freeman, eds., Immigration, Trade, and the Labor Market. Chicago, IL: University of Chicago Press, pp. 77-100.

Borjas, G.J. and L. Hilton. 1996. "Immigration and the Welfare State: Immigrant Participation in Means-Tested Entitlement Programs." Quarterly Journal of Economics 106: 575-604.

Bustamante, Jorge. 1990. "Undocumented Migration from Mexico to the United States: Preliminary Findings of the Zapata Canyon Project," in Frank D. Bean, Barry Edmonston, and Jeffrey S. Passel, eds., Undocumented migration to the United States: IRCA and the experience of the 1980's. Washington, DC: The Urban Institute, pp. 211-226.

Card, D.E. 1997. "Immigrant Inflows, Native Outflows, and the Local Labor Market Impacts of Higher Immigration." NBER Working Paper No. 5927. 
Cornelius, Wayne A. 1992. "From Sojourners to Settlers: The Changing Profile of Mexican Immigration to the United States," in Jorge A. Bustamente, Clark W. Reynolds, and Raul A. Hinojosa, eds., U.S.-Mexico Relations: Labor-market Interdependence. Stanford, CA: Stanford University Press, pp. 155-95.

Donato, Katherine M.; Durand, Jorge and Massey, Douglas S. 1992. "Stemming the Tide? Assessing the Deterrent Effects of U.S. Immigration and Control." Demogrophy, May, 29(2), pp. 139-57.

Donato, Katherine M., and Massey, Douglas S. 1992. "Mexican Migration to the United States: A Critical Review." Latin American Research Review, 27: 3-43.

Espenshade, Thomas J. "Does the Threat of Border Apprehension Deter Undocumented U.S. Immigration?" Population and Development Review, December 1994, 20(4), pp. 871-91.

Espenshade, Thomas J. "Unauthorized Immigration to the United States." Annual Review of Sociology Vol. 21, 1995, pp. 195-216.

Filer, R.K. 1992. "The Effect of Immigrant Arrivals on Migratory Patterns of Native Workers." In G.J. Borjas and R.B. Freeman, eds., Immigration and the Work Force. Chicago: University of Chicago Press.

Friedberg, Rachel M. and Hunt, Jennifer. "The Impact of Immigrants on Host-Country Wages, Employment, and Growth." Journal of Economic Perspectives, Spring 1995, 9(2), pp. 23-44.

Godfrey, L.G. 1994. "Testing for Serial Correlation by Variable Addition in Dynamic Models Estimated by Instrumental Variables." The Review of Economics and Statistics 76: 550-559.

Grossman, J.B. 1982. "The Substitutability of Natives and Immigrants in Production." Review of Economics and Statistics 54: 596-603.

Hamilton, J.D. 1994. Time Series A nalysis. Princeton, NJ: Princeton University Press.

Hanson, G.H. and A. Spilimbergo. 1999. "Illegal Immigration, Border Enforcement, and Relative Wages: Evidence from Apprehensions at the U.S.-Mexico Border," American Economic Review, forthcoming.

Hanson, G.H. and M.J. Slaughter. 1999. "Factor-Price Insensitivity to Immigration and the Rybczynski Theorem: Evidence from U.S. States." Mimeo, University of Michigan.

Katz, L. and K.M. Murphy. 1992. "Changes in Relative Wages, 1963-1987: Supply and Demand Factors." Quarterly Journal of Economics 107: 35-78.

LaLonde, R.J. and R.H. Topel. 1991. "Labor Market Adjustments to Increased Immigration." 
In J.M. Abowd and R.B. Freeman, eds., Immigration, Trade, and the Labor Market. Chicago: University of Chicago Press, pp. 167-99.

Levy, F. and R.J. Murnane. 1992. "U.S. Earnings Levels and Earnings Inequality: A Review of Recent Trends and Proposed Explanations." Journal of Economic Literature 30: 1333-1382.

Orrenius, P. 1987. "The Role of Income Shocks on Migration Behavior and Migrant SelfSelection: The Case of Return Migrants from Mexico, 1970-1988." Mimeo, UCLA.

Robertson, R. 1998. "Wage Shocks and North American Labor Market Integration." Mimeo, Syracuse University.

Schoeni, R.F. 1997. "The Effect of Immigrants on the Employment of Wages of Native Workers: Evidence from the 1970s and 1980s." Mimeo, RAND.

Topel, R.H. 1986. "Local Labor Markets." Journal of Political Economy 94: S111-S143.

U.S. Immigration and Naturalization Service, Department of Justice. 1994 Statistical Yearbook of the Immigration and Naturalization Service. Washington, D.C.: U.S. Government Printing Office, 1996.

Warren, Robert. "Estimates of the Undocumented Immigrant Population Residing in the United States, by Country of Origin and State of Residence: October 1992." Washington, D.C.: U.S. Immigration and Naturalization Service, Department of Justice, 1995. 
Table 1a: Mexican-bom Shares of Industry Employment by Year and Region, Recent Arrivals

\begin{tabular}{|c|c|c|c|c|c|c|c|c|c|c|}
\hline \multirow{3}{*}{ Industry } & \multicolumn{4}{|c|}{ California } & \multicolumn{4}{|c|}{$\underline{\text { Texas }}$} & \multicolumn{2}{|c|}{ Rest of U.S. } \\
\hline & \multicolumn{2}{|c|}{ Border } & \multicolumn{2}{|c|}{ Entire State } & \multicolumn{2}{|c|}{ Border } & \multicolumn{2}{|c|}{ Entire State } & & \\
\hline & $\underline{80}$ & $\underline{90}$ & $\underline{80}$ & $\underline{90}$ & $\underline{80}$ & 90 & $\underline{80}$ & $\underline{90}$ & $\underline{80}$ & $\underline{90}$ \\
\hline Food & $0 . \overline{070}$ & 0.090 & 0.041 & 0.040 & $0 . \overline{040}$ & $0 . \overline{009}$ & $0 . \overline{029}$ & $0 . \overline{052}$ & $0 . \overline{004}$ & $0 . \overline{005}$ \\
\hline Textiles & 0.129 & 0.138 & 0.105 & 0.085 & 0.033 & 0.047 & 0.023 & 0.007 & 0.000 & 0.001 \\
\hline Apparel & 0.149 & 0.131 & 0.122 & 0.035 & 0.060 & 0.018 & 0.030 & 0.018 & 0.002 & 0.002 \\
\hline Lumber & 0.104 & 0.119 & 0.029 & 0.022 & 0.018 & 0.046 & 0.018 & 0.014 & 0.001 & 0.001 \\
\hline Furn & 0.116 & 0.131 & 0.089 & 0.039 & 0.015 & 0.015 & 0.021 & 0.017 & 0.003 & 0.002 \\
\hline Constrn. & 0.022 & 0.066 & 0.014 & 0.024 & 0.038 & 0.027 & 0.026 & 0.015 & 0.001 & 0.002 \\
\hline Restrnt. & 0.047 & 0.083 & 0.008 & 0.011 & 0.008 & 0.009 & 0.005 & 0.003 & 0.000 & 0.001 \\
\hline Ret. & 0.012 & 0.005 & 0.030 & 0.033 & 0.019 & 0.020 & 0.014 & 0.013 & 0.001 & 0.004 \\
\hline
\end{tabular}

Table 1b: Mexican-bom Shares of Industry Employment by Year and Region, All Mexican Bom

\begin{tabular}{|c|c|c|c|c|c|c|c|c|c|c|}
\hline \multirow{3}{*}{ Industry } & \multicolumn{4}{|c|}{$\underline{\text { California }}$} & \multicolumn{4}{|c|}{ Texas } & \multicolumn{2}{|c|}{$\underline{\text { Rest of U.S. }}}$. \\
\hline & & & Enti & State & & ler & Enti & State & & \\
\hline & $\frac{80}{20}$ & 90 & $\underline{80}$ & $\underline{90}$ & $\underline{80}$ & $\underline{90}$ & $\underline{80}$ & $\underline{90}$ & 80 & $\underline{90}$ \\
\hline Food & 0.237 & $0 . \overline{338}$ & 0.167 & 0.269 & 0.157 & $0 . \overline{216}$ & $0 . \overline{089}$ & $0 . \overline{190}$ & $0 . \overline{010}$ & $0 . \overline{022}$ \\
\hline Textiles & 0.413 & 0.475 & 0.352 & 0.394 & 0.150 & 0.281 & 0.097 & 0.1 & 0.002 & 0.005 \\
\hline Apparel & 0.403 & 0.430 & 0.335 & 0.366 & 0.295 & 0.459 & 0.153 & 0.279 & 0.005 & 0.007 \\
\hline Lumber & 0.238 & 0.396 & 0.087 & 0.175 & 0.109 & 0.1 & 0.074 & 0.122 & 0.003 & 0.005 \\
\hline Furn. & 0.411 & 0.453 & 0.320 & 0.367 & 0.103 & 0.162 & 0.069 & 0.120 & 0.007 & 0.010 \\
\hline Constrn & 0.085 & 0.188 & 0.055 & 0.133 & 0112 & 0.193 & 0.072 & & 0.0 & 0.007 \\
\hline Restrnt. & 0.111 & 0.240 & 0.034 & 0.1 & 0.0 & 0.1 & 0.026 & & 0.002 & 0.010 \\
\hline Ret. Trd & 0.049 & 0.110 & 0.073 & 80 & 0.069 & 0.075 & 0.043 & 0.046 & 0.003 & 0.004 \\
\hline
\end{tabular}

Source: Authors' calculations using data are from the 1980 and 1990 1\% Public Use Micro Samples of the U.S. Population and Housing Census. Figures shown are the share of regional industry workers who are Mexican immigrants. Recent arrivals are those who immigrated within the five-year period preceding the census date. The Rest of the U.S. is all U.S. states except California and Texas. Individuals whose usual hours of weekly work are less than 10 or whose usual weekly earnings are less than $\$ 1$ are excluded from the sample. Industries shown are food products, textiles, apparel, lumber, furniture, construction, restaurants/lodging, and retail trade. 
Table 2: Summary Statistics

(a) Variables for Wage-Growth Regressions in U.S. Border Regions

\begin{tabular}{|c|c|c|c|}
\hline \multicolumn{2}{|c|}{ Variable Name Variable Definition } & \multirow{2}{*}{$\begin{array}{l}\text { Mean } \\
4.896\end{array}$} & \multirow{2}{*}{$\begin{array}{l}\text { Std.Error } \\
0.223\end{array}$} \\
\hline $\begin{array}{l}\text { California Wage- } \\
\text { HS Dropout }\end{array}$ & $\begin{array}{l}\text { Age-adjusted mean wage for male high-school } \\
\text { dropouts in southern California MSAs. }\end{array}$ & & \\
\hline $\begin{array}{l}\text { Califormia Wage- } \\
\text { HS Graduate }\end{array}$ & $\begin{array}{l}\text { Age-adjusted mean wage for male high-school } \\
\text { graduates in southern California MSAs. }\end{array}$ & 5.237 & 0.142 \\
\hline $\begin{array}{l}\text { Texas Wage- } \\
\text { HS Dropout }\end{array}$ & $\begin{array}{l}\text { Age-adjusted mean wage for male high-school } \\
\text { dropouts in southwestern Texas MSAs. }\end{array}$ & 4.712 & 0.171 \\
\hline $\begin{array}{l}\text { Texas Wage- } \\
\text { HS Graduate }\end{array}$ & $\begin{array}{l}\text { Age-adjusted mean wage for male high-school } \\
\text { graduates in southwestern Texas MSAs. }\end{array}$ & 5.051 & 0.129 \\
\hline $\begin{array}{l}\text { US Wage- } \\
\text { HS Dropout }\end{array}$ & $\begin{array}{l}\text { Age-adjusted mean wage for male high-school } \\
\text { dropouts in U.S., excluding California and Texas. }\end{array}$ & 4.815 & 0.139 \\
\hline $\begin{array}{l}\text { US Wage- } \\
\text { HS Graduate }\end{array}$ & $\begin{array}{l}\text { Age-adjusted mean wage for male high-school } \\
\text { graduates in U.S., excluding California and Texas. }\end{array}$ & 5.128 & 0.095 \\
\hline Mexico Wage & $\begin{array}{l}\text { Average hourly real wage for production workers } \\
\text { in manufacturing industries. }\end{array}$ & -0.056 & 0.108 \\
\hline $\begin{array}{l}\text { Border Enforcement- } \\
\text { California }\end{array}$ & $\begin{array}{l}\text { Enforcement hours by U.S. Border Patrol in } \\
\text { California Border Patrol sectors. }\end{array}$ & 11.188 & 0.179 \\
\hline $\begin{array}{l}\text { Border Enforcement- } \\
\text { Texas }\end{array}$ & $\begin{array}{l}\text { Enforcement hours by U.S. Border Patrol in } \\
\text { Texas Border Patrol sectors. }\end{array}$ & 11.563 & 0.182 \\
\hline
\end{tabular}

All figures are in logs and at a monthly frequency for January, 1986 to May, 1995. For expositional ease, we exclude summary statistics on log wages for the food products, textiles, apparel, lumber, and furniture industries in California, Texas, and the rest of the United States. Wages for these industries are shown in Figures 3 and 4. 
Table 2: Continued

(b) Variables for Wage-Growth Regressions in Mexico Border Cities

\begin{tabular}{|c|c|c|c|}
\hline \multicolumn{2}{|c|}{ Variable Name Variable Definition } & \multirow{2}{*}{$\begin{array}{l}\text { Mean } \\
1.467\end{array}$} & \multirow{2}{*}{$\begin{array}{l}\text { Std.Error } \\
0.103\end{array}$} \\
\hline $\begin{array}{l}\text { Cd. Juarez Wage- } \\
\text { Primary }\end{array}$ & $\begin{array}{l}\text { Age-adjusted mean wage for males in } \mathrm{Cd} \text {. Juarez } \\
\text { with primary ( } 0-6 \text { years) education. }\end{array}$ & & \\
\hline $\begin{array}{l}\text { Cd. Juarez Wage- } \\
\text { Secondary }\end{array}$ & $\begin{array}{l}\text { Age-adjusted mean wage for males in Cd. Juarez } \\
\text { with secondary ( } 7-11 \text { years) education. }\end{array}$ & 1.641 & 0.099 \\
\hline $\begin{array}{l}\text { Tijuana Wage- } \\
\text { Primary }\end{array}$ & $\begin{array}{l}\text { Age-adjusted mean wage for males in Tijuana with } \\
\text { primary (0-6 years) education. }\end{array}$ & 1.776 & 0.132 \\
\hline $\begin{array}{l}\text { Tijuana Wage- } \\
\text { Secondary }\end{array}$ & $\begin{array}{l}\text { Age-adjusted mean wage for males in Tijuana with } \\
\text { secondary ( } 7-11 \text { years) education. }\end{array}$ & 1.927 & 0.112 \\
\hline $\begin{array}{l}\text { Mexico Wage- } \\
\text { Primary }\end{array}$ & $\begin{array}{l}\text { Age-adjusted mean wage for males in Mexico } \\
\text { interior cities with primary ( } 0-6 \text { years) education. }\end{array}$ & 1.278 & 0.088 \\
\hline $\begin{array}{l}\text { Mexico Wage- } \\
\text { Secondary }\end{array}$ & $\begin{array}{l}\text { Age-adjusted mean wage for males in Mexico } \\
\text { interior cities with secondary ( } 7-11 \text { years) education. }\end{array}$ & 1.467 & 0.075 \\
\hline $\begin{array}{l}\text { Border Enforcement- } \\
\text { Tijuana }\end{array}$ & $\begin{array}{l}\text { Enforcement hours by U.S. Border Patrol in San } \\
\text { Diego sector. }\end{array}$ & 12.065 & 0.272 \\
\hline $\begin{array}{l}\text { Border Enforcement- } \\
\text { Cd. Juarez }\end{array}$ & $\begin{array}{l}\text { Enforcement hours by U.S. Border Patrol in El } \\
\text { Paso sector. }\end{array}$ & 11.580 & 0.297 \\
\hline
\end{tabular}

All figures are in logs at a quarterly frequency for the first quarter, 1987 through the fourth quarter, 1997. 


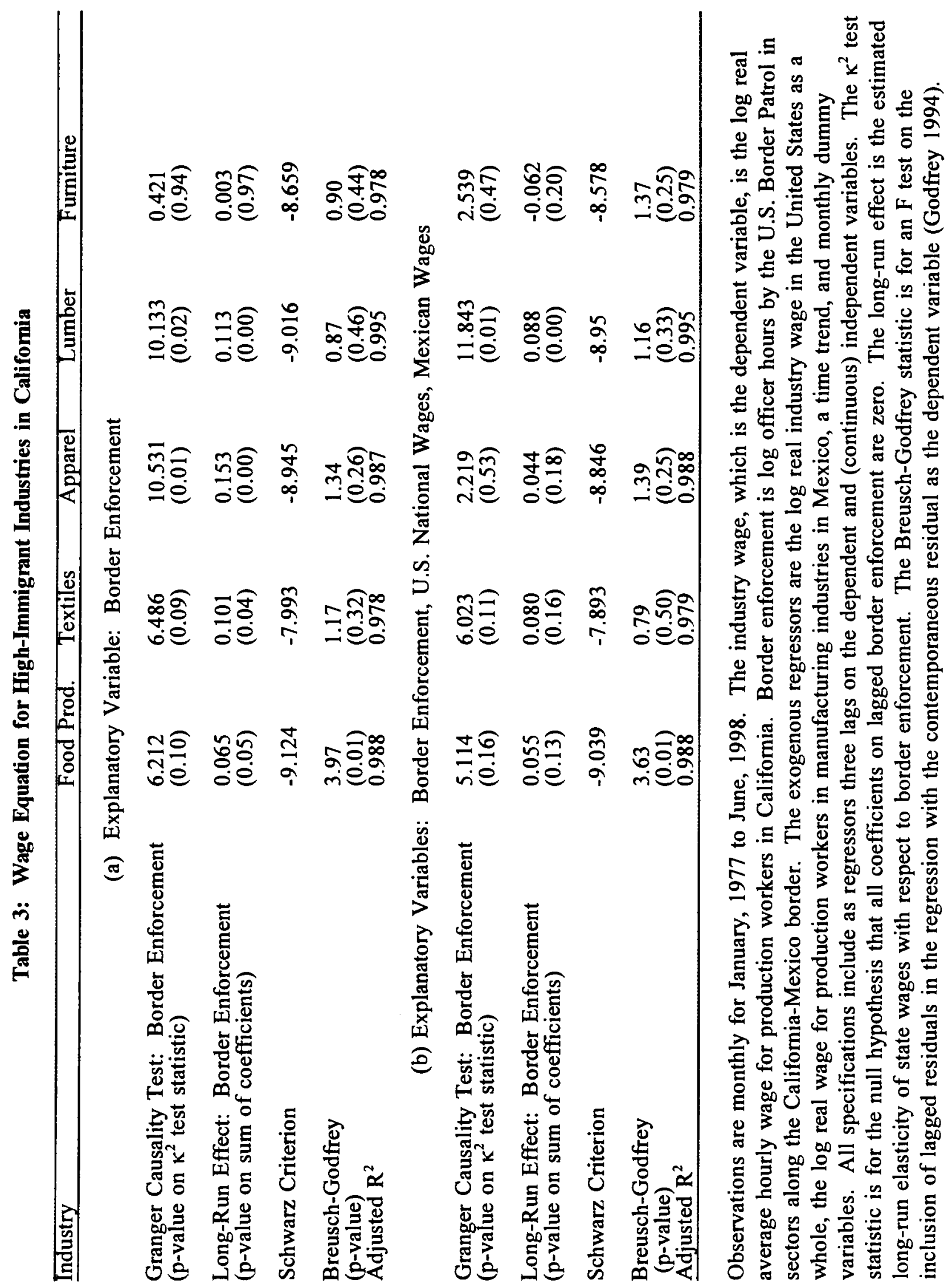




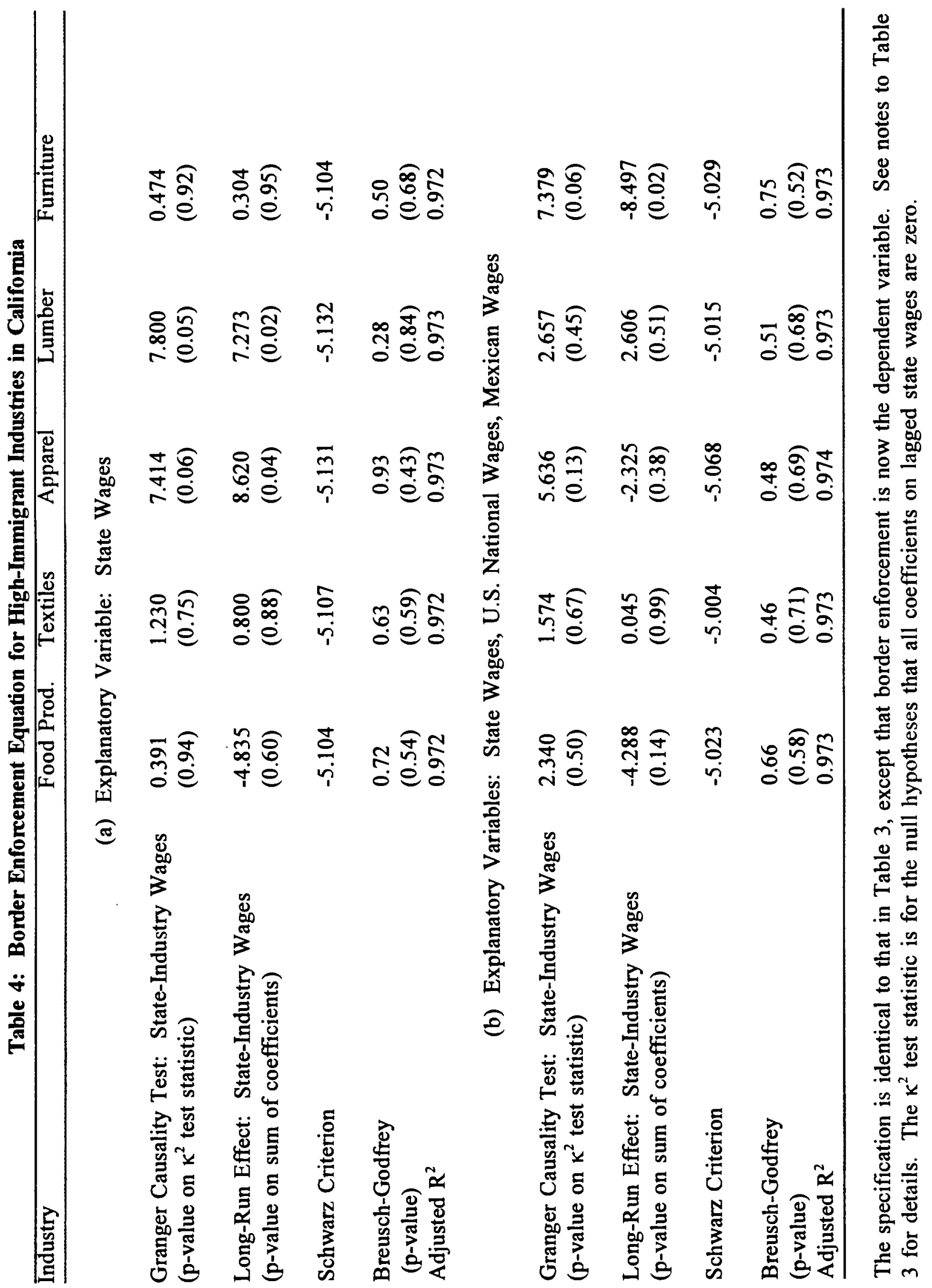




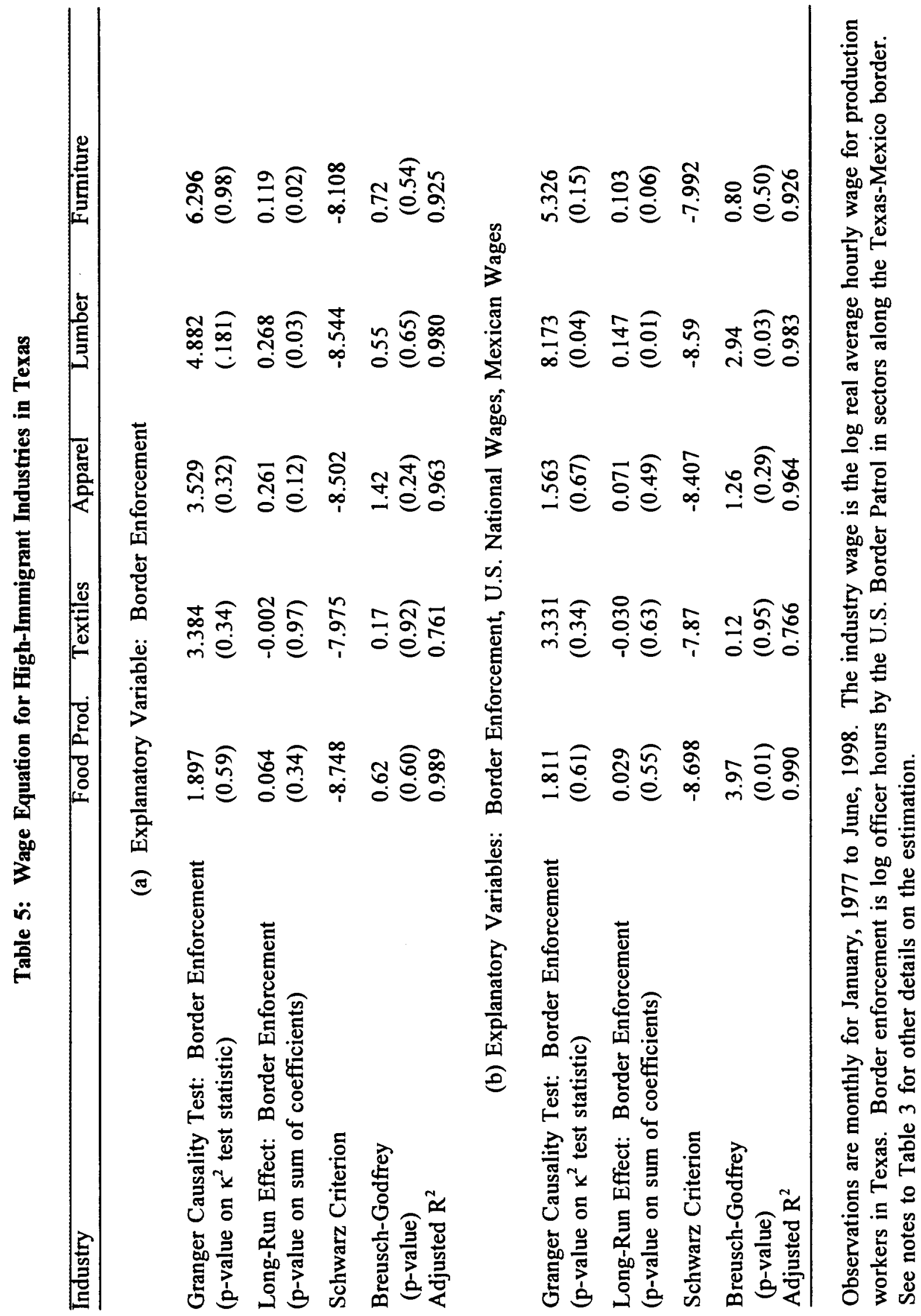




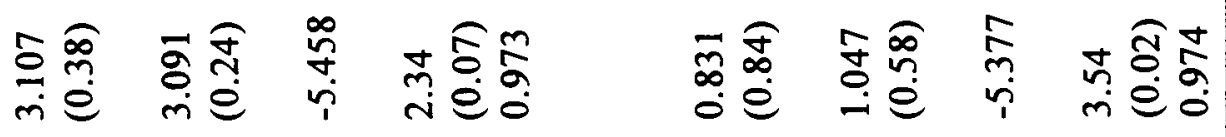

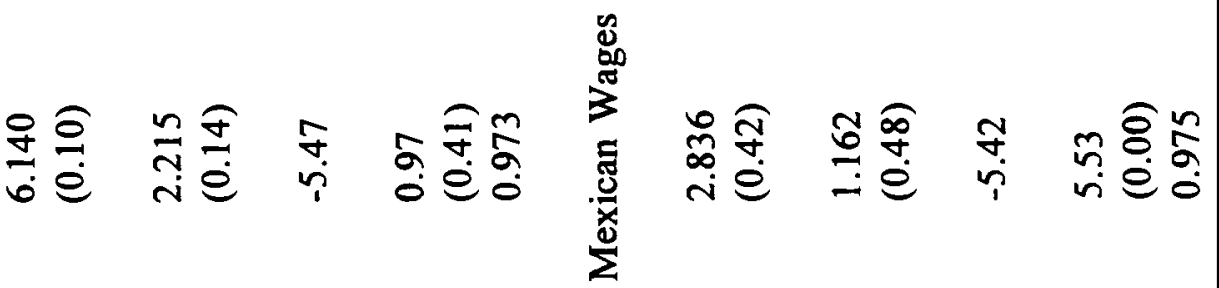

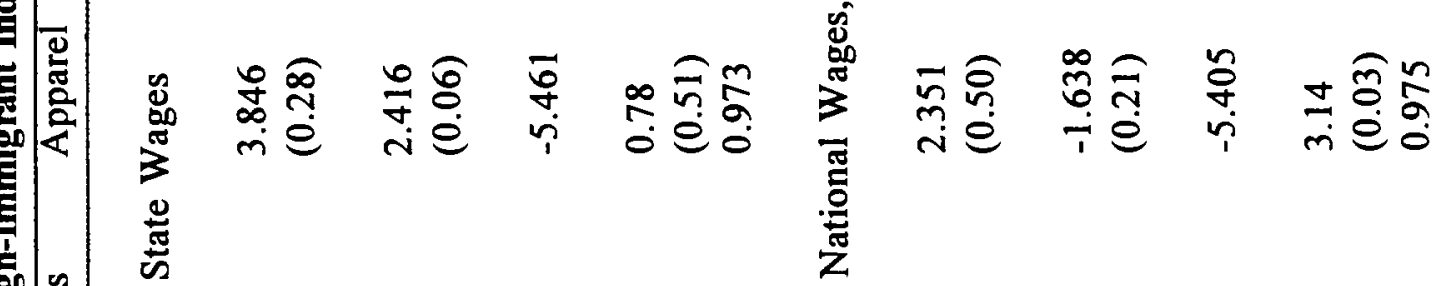

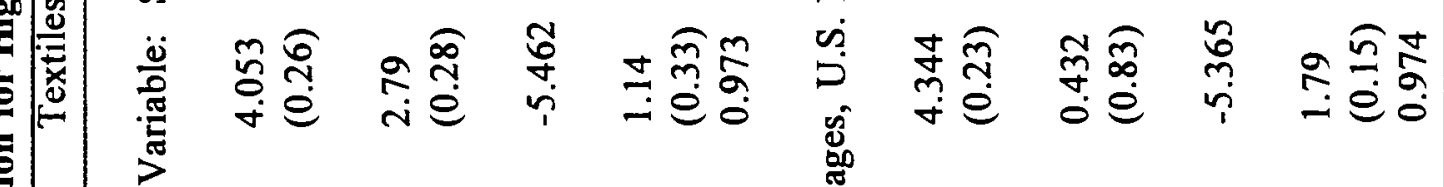

2

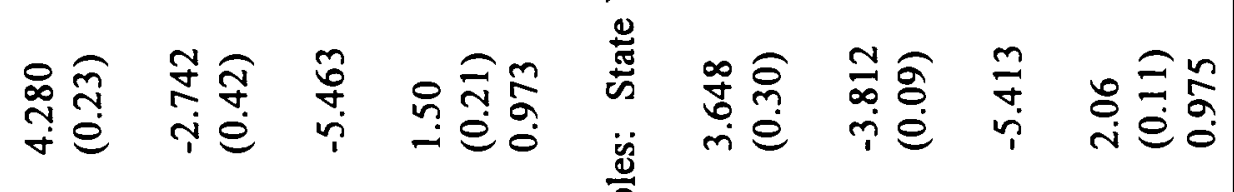

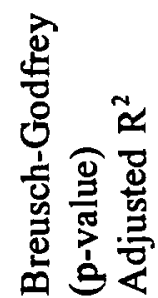

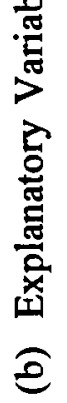

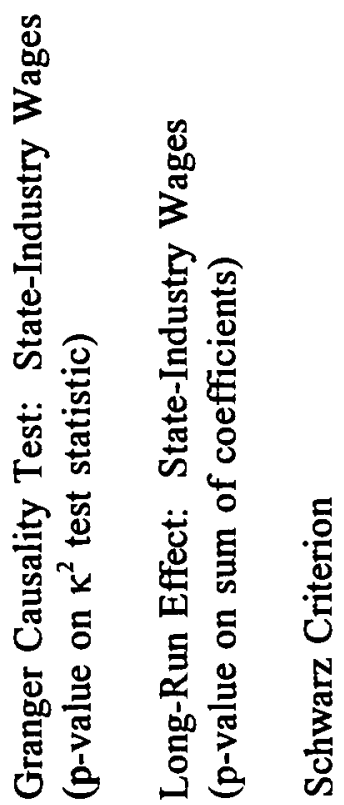




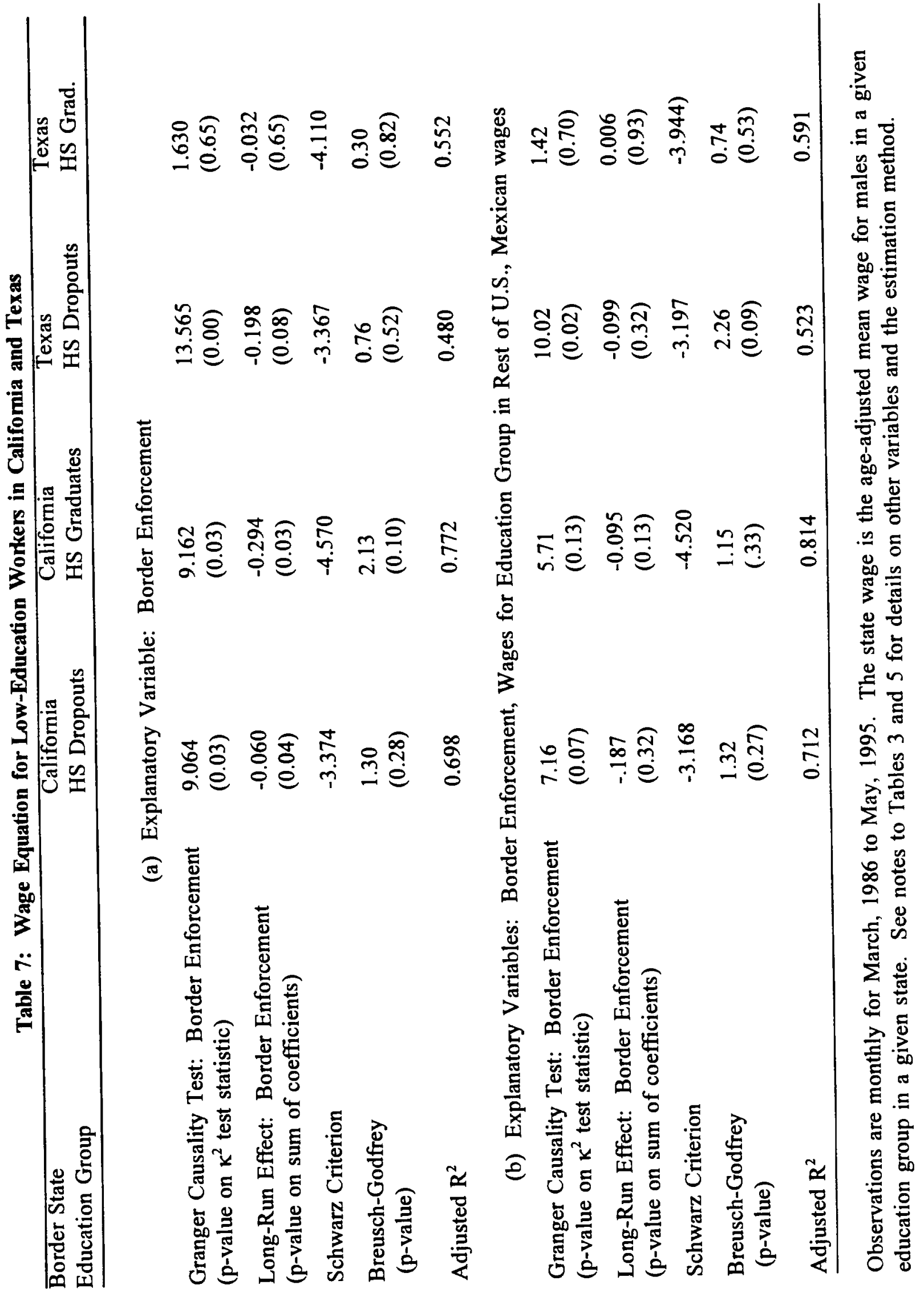




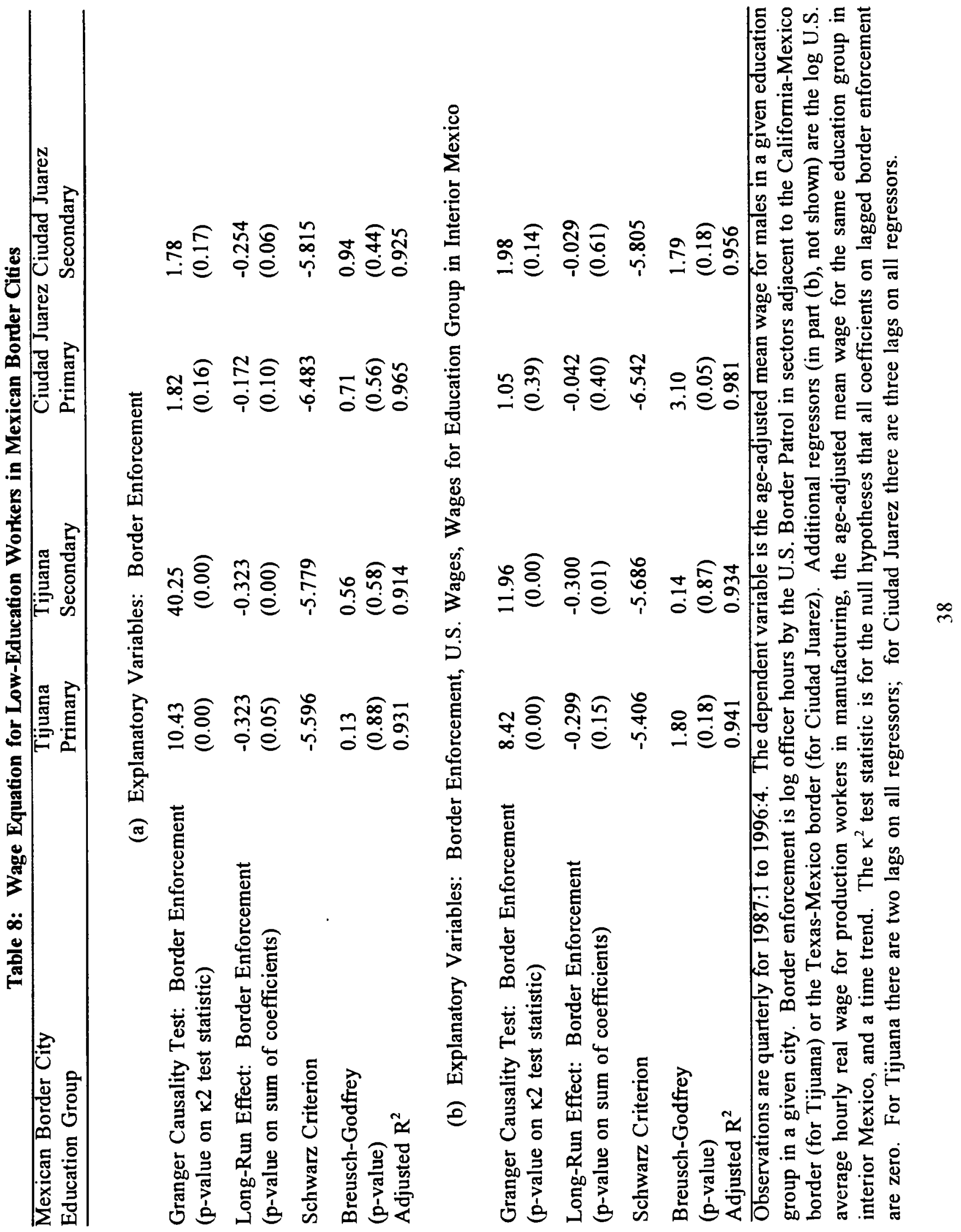




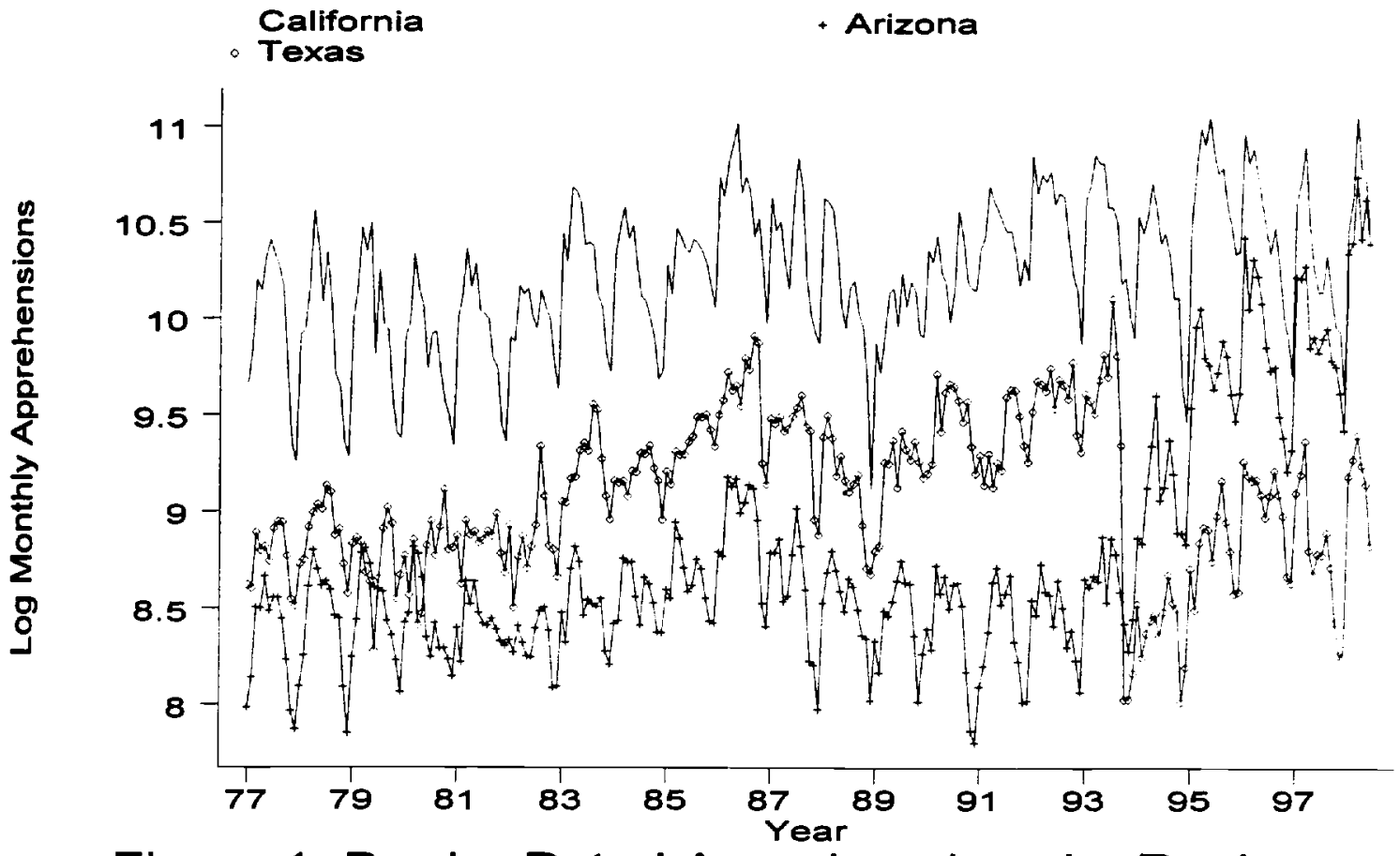

Figure 1: Border Patrol Apprehensions by Region 


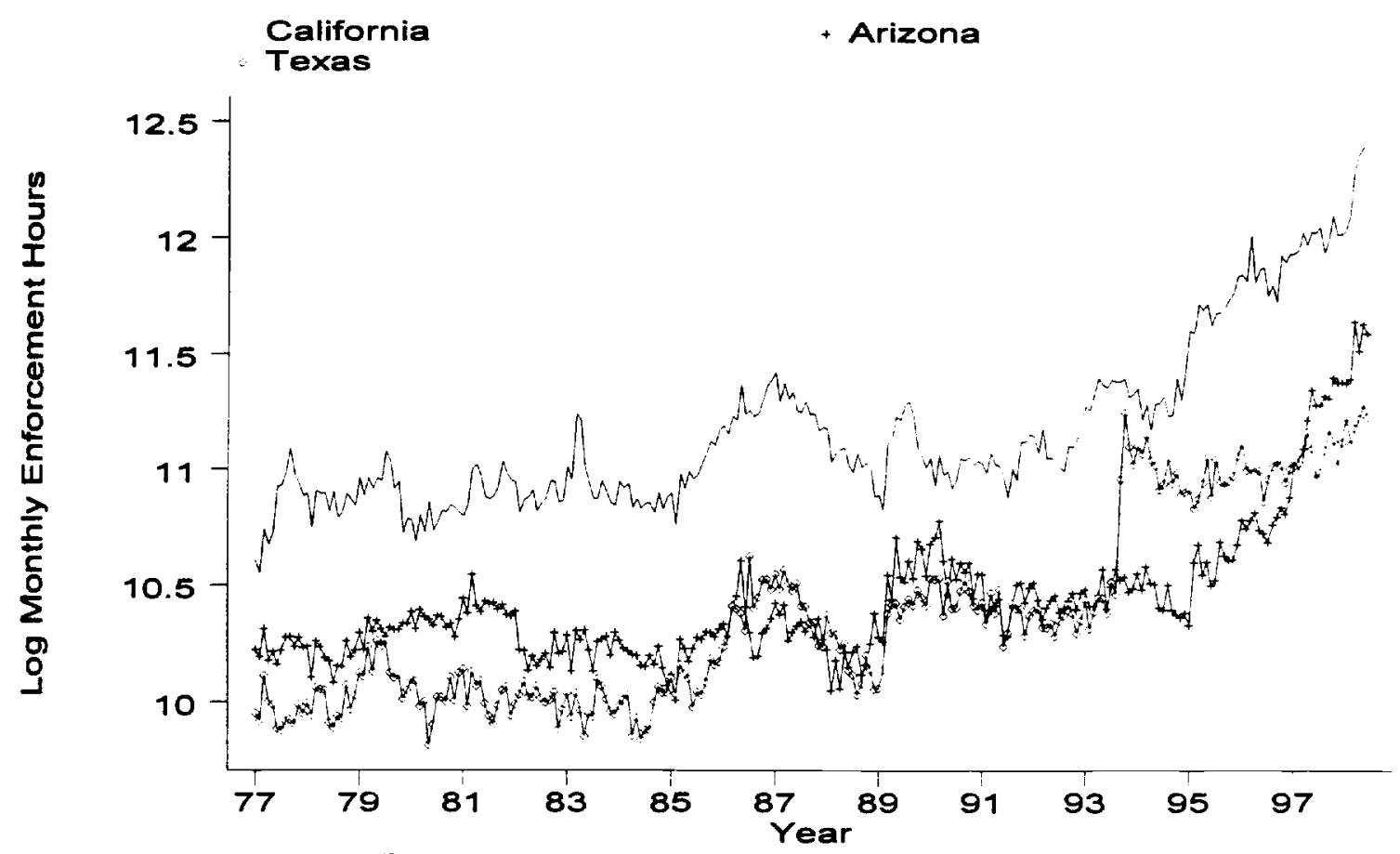

Figure 2: Border Patrol Enforcement by Region 


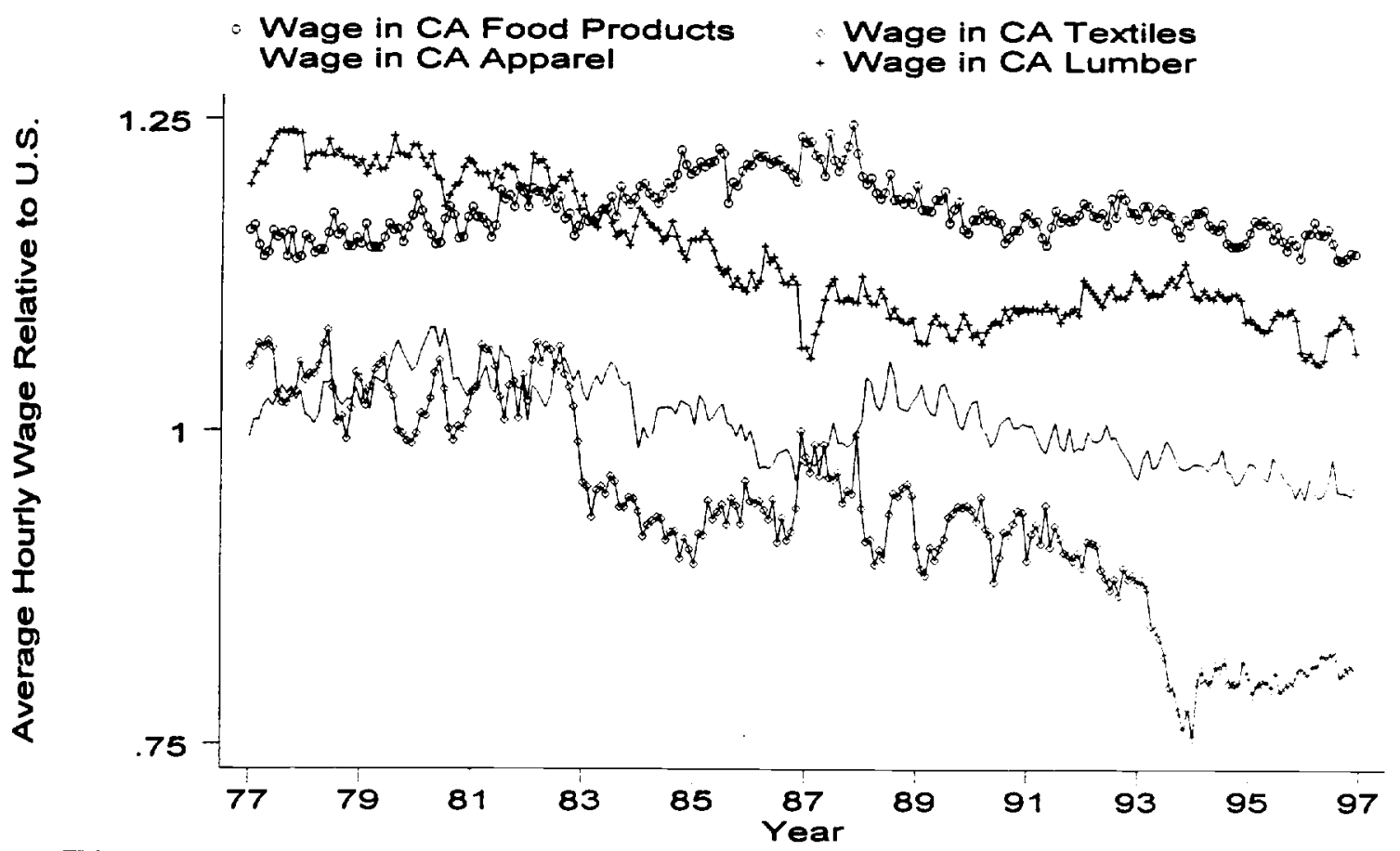

Figure 3: Wages in High-Immigrant California Industry 


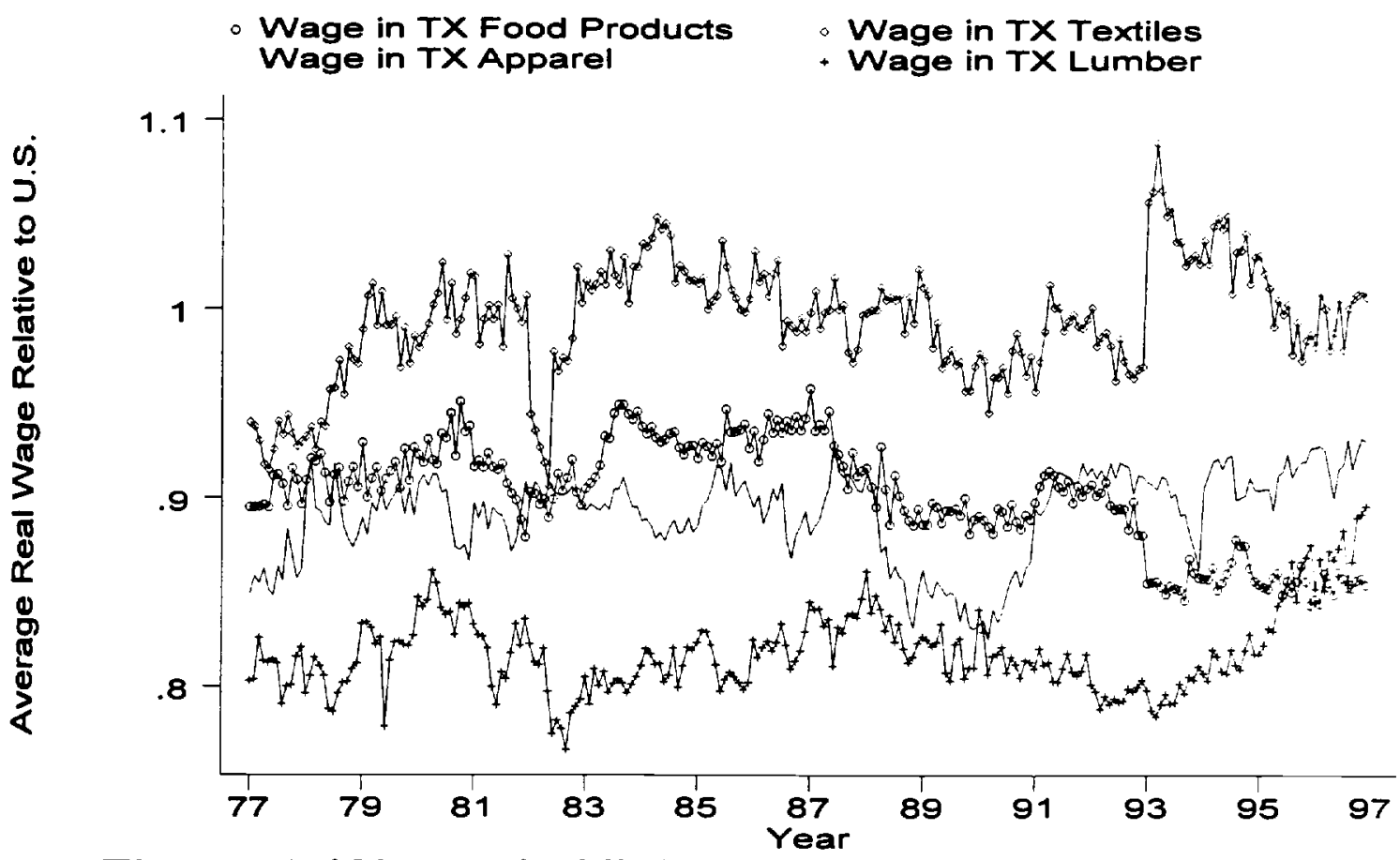

Figure 4: Wages in High-Immigrant Texas Industry 


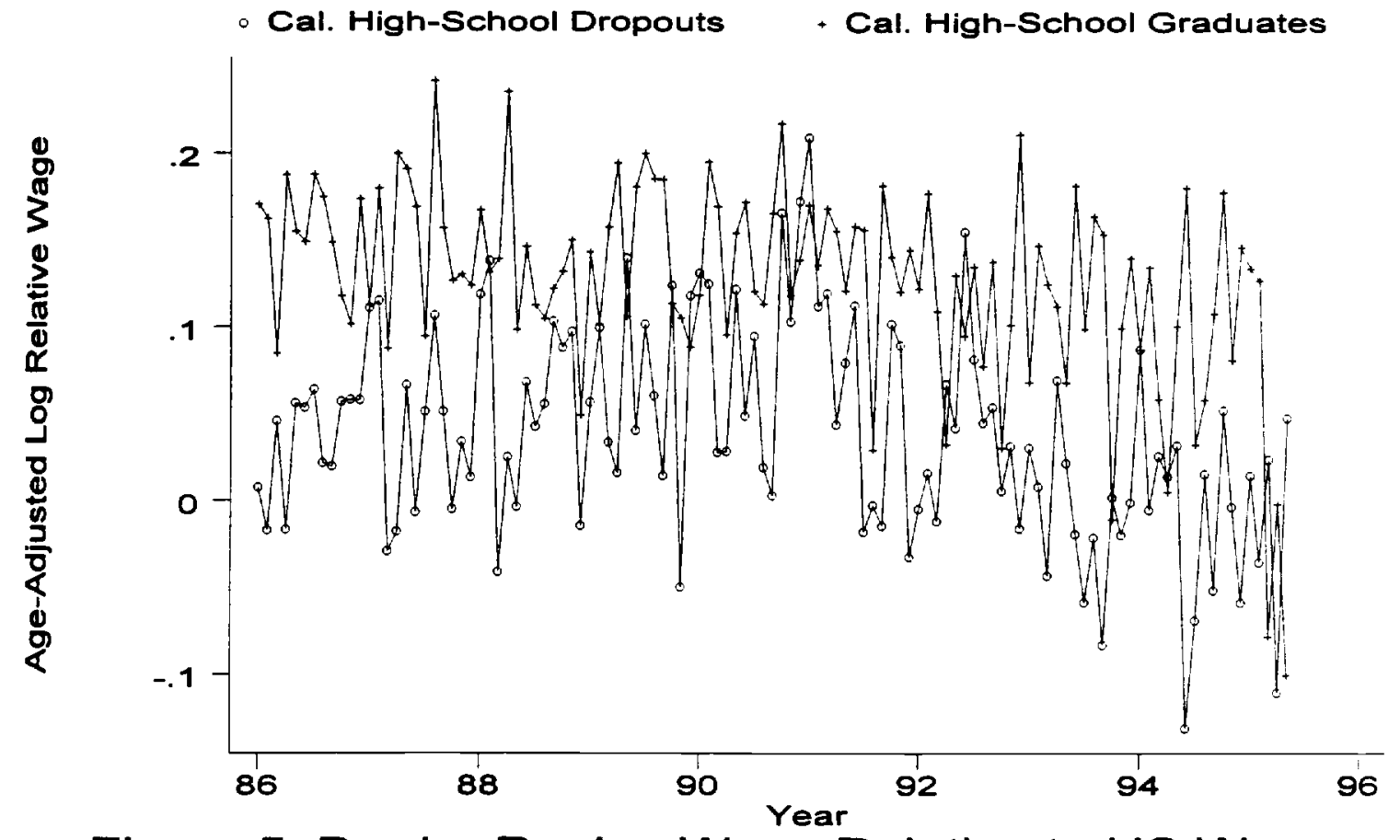

Figure 5: Border Region Wage Relative to US Wage 


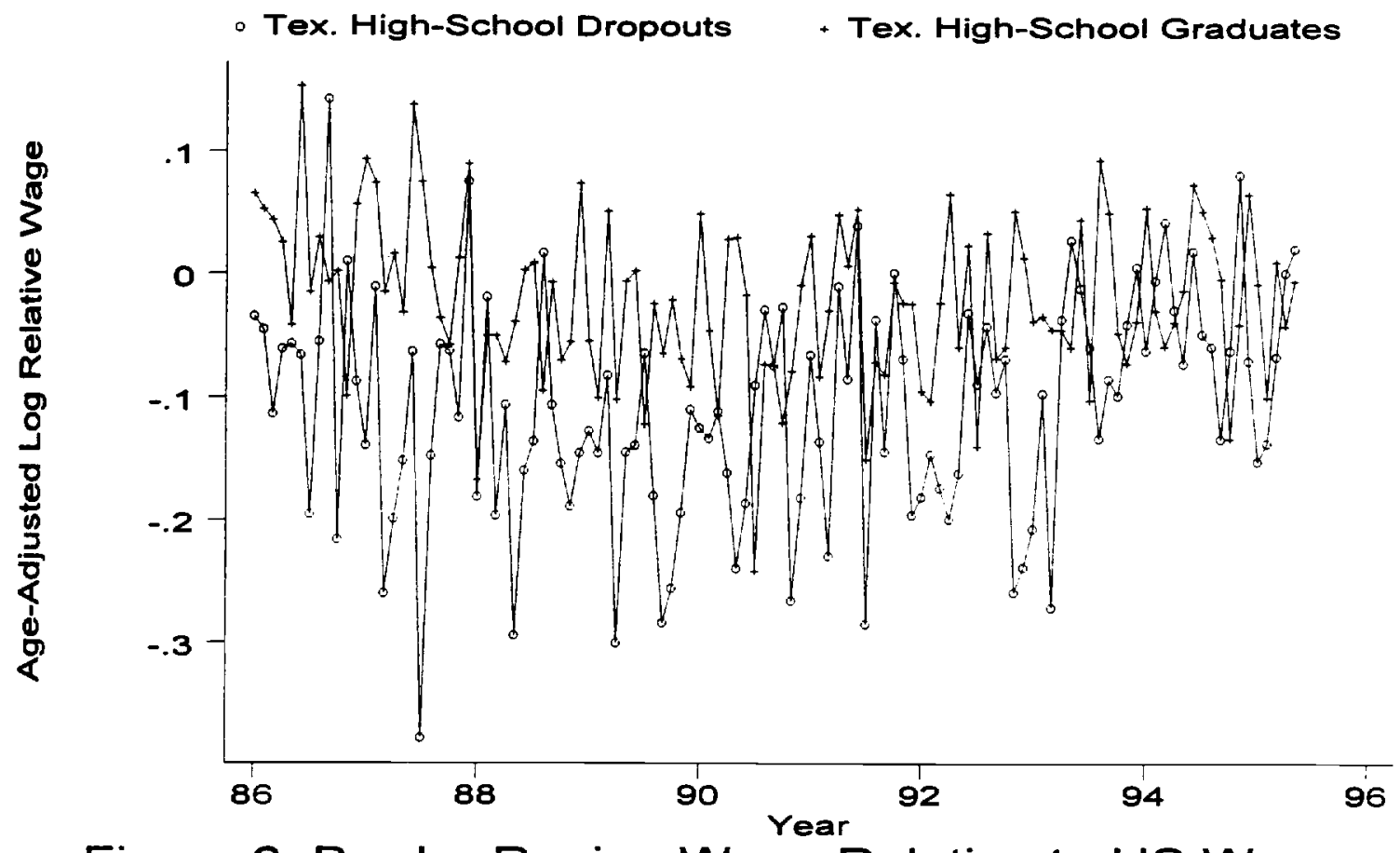

Figure 6: Border Region Wage Relative to US Wage 


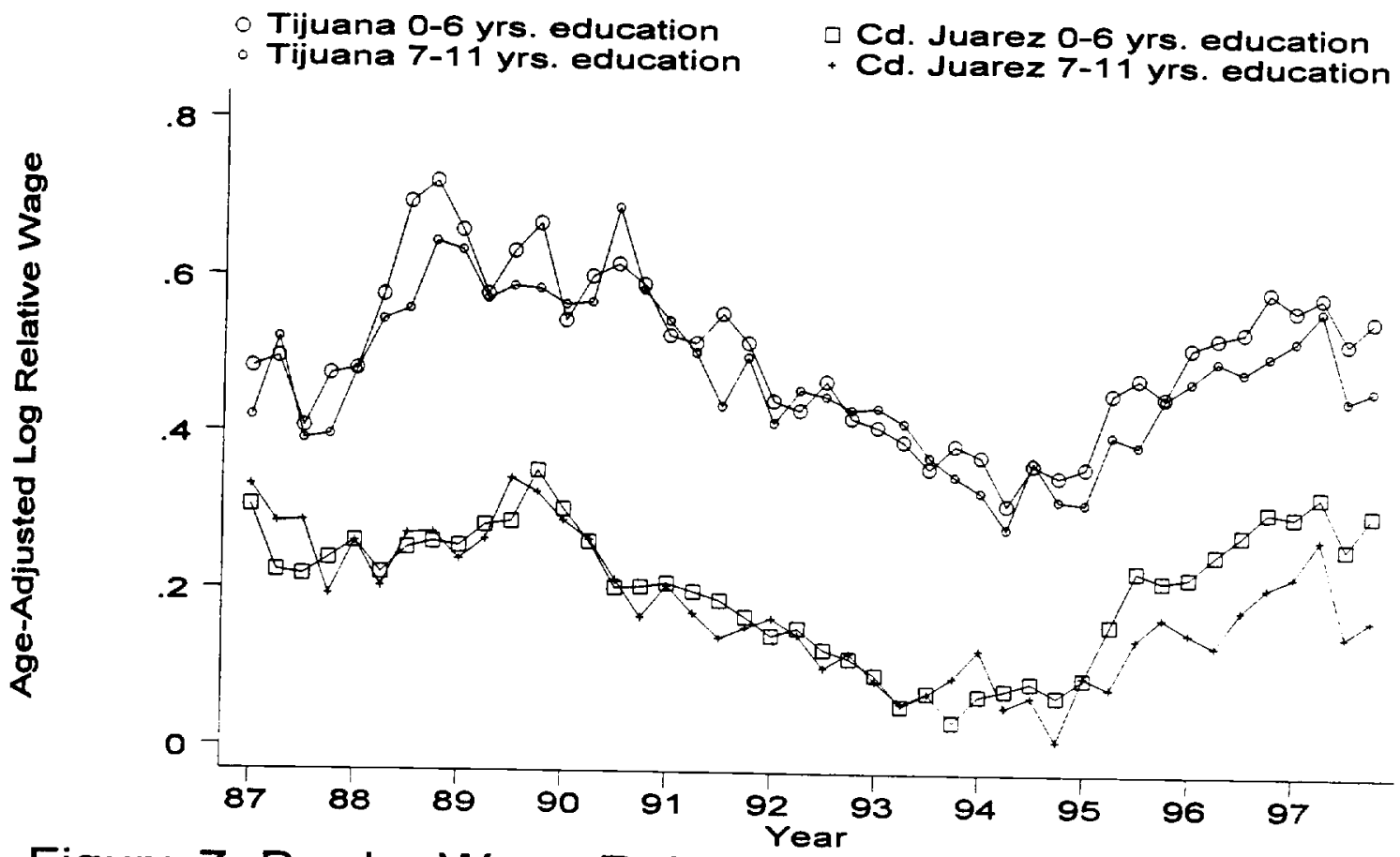

Figure 7: Border Wage Relative to Interior Mexico Wage 


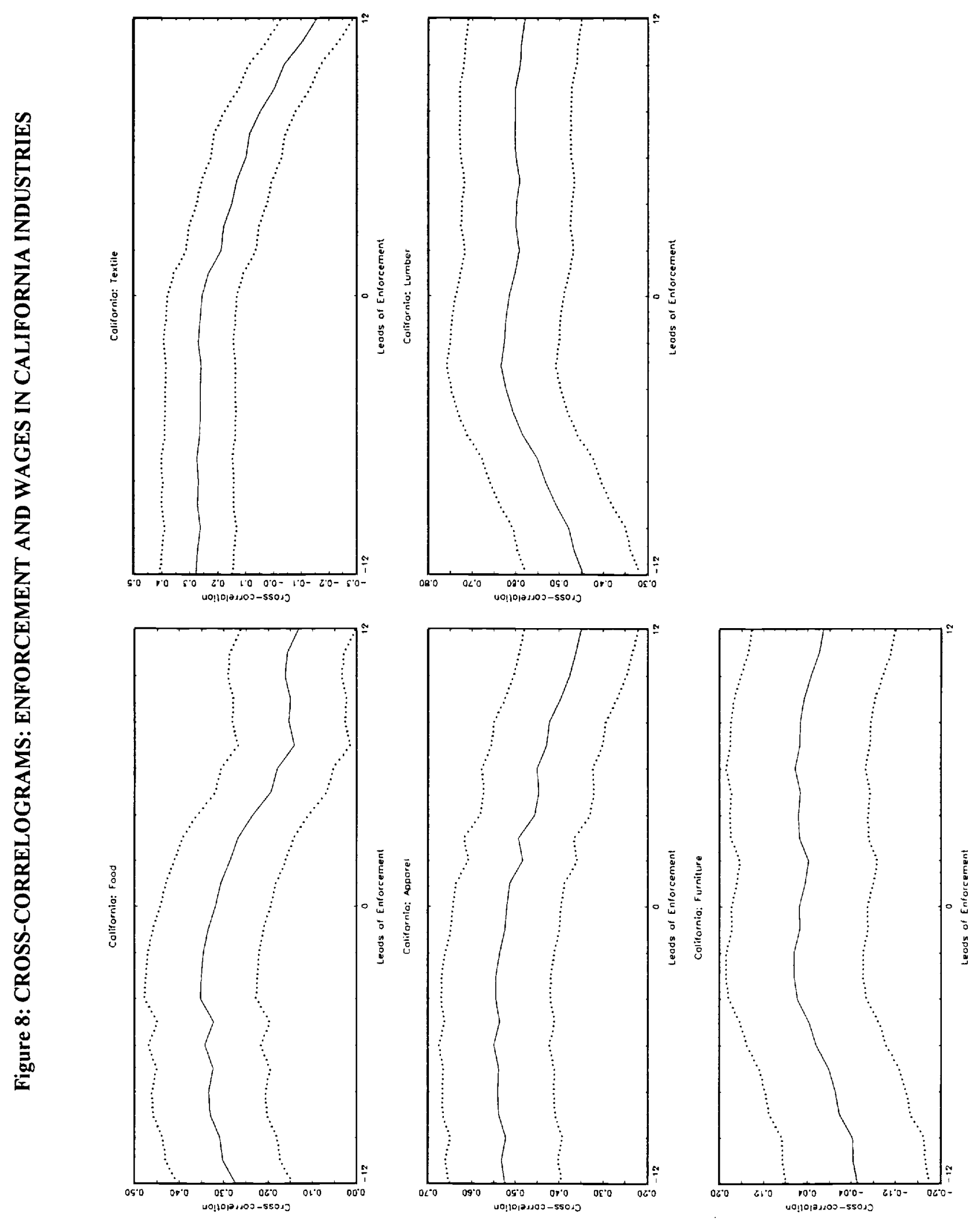



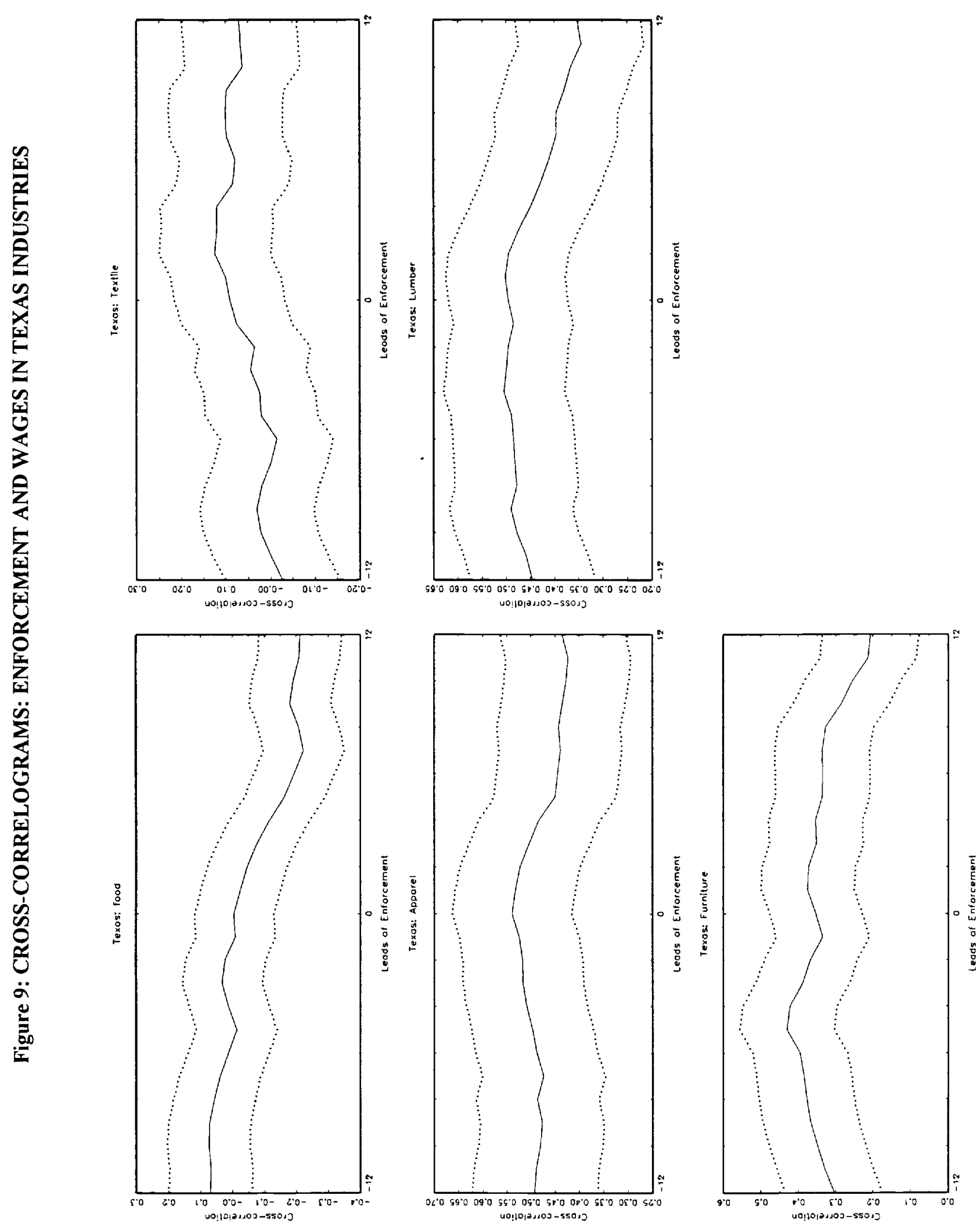

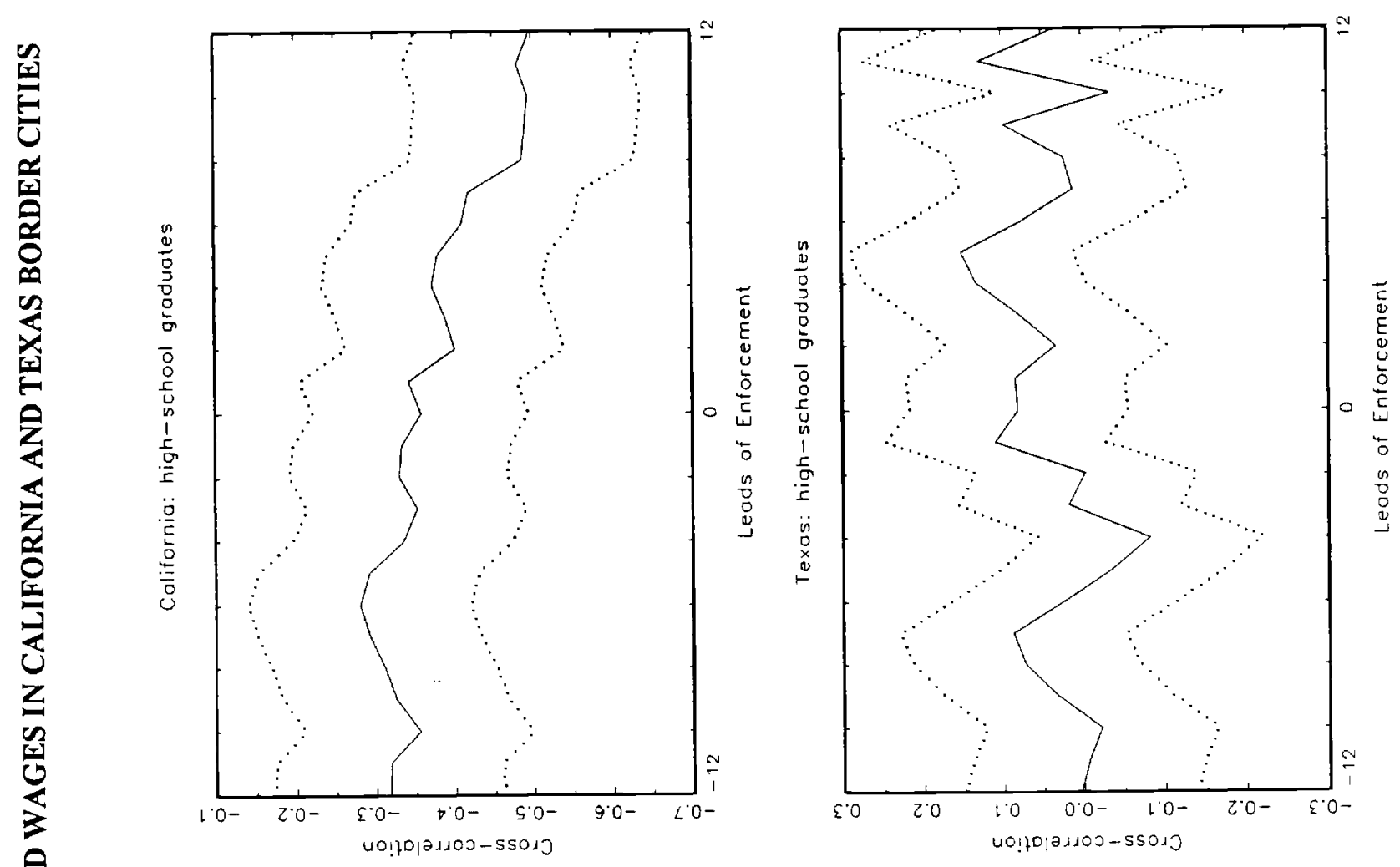

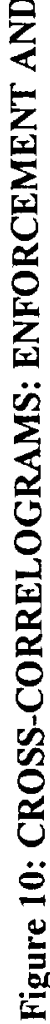
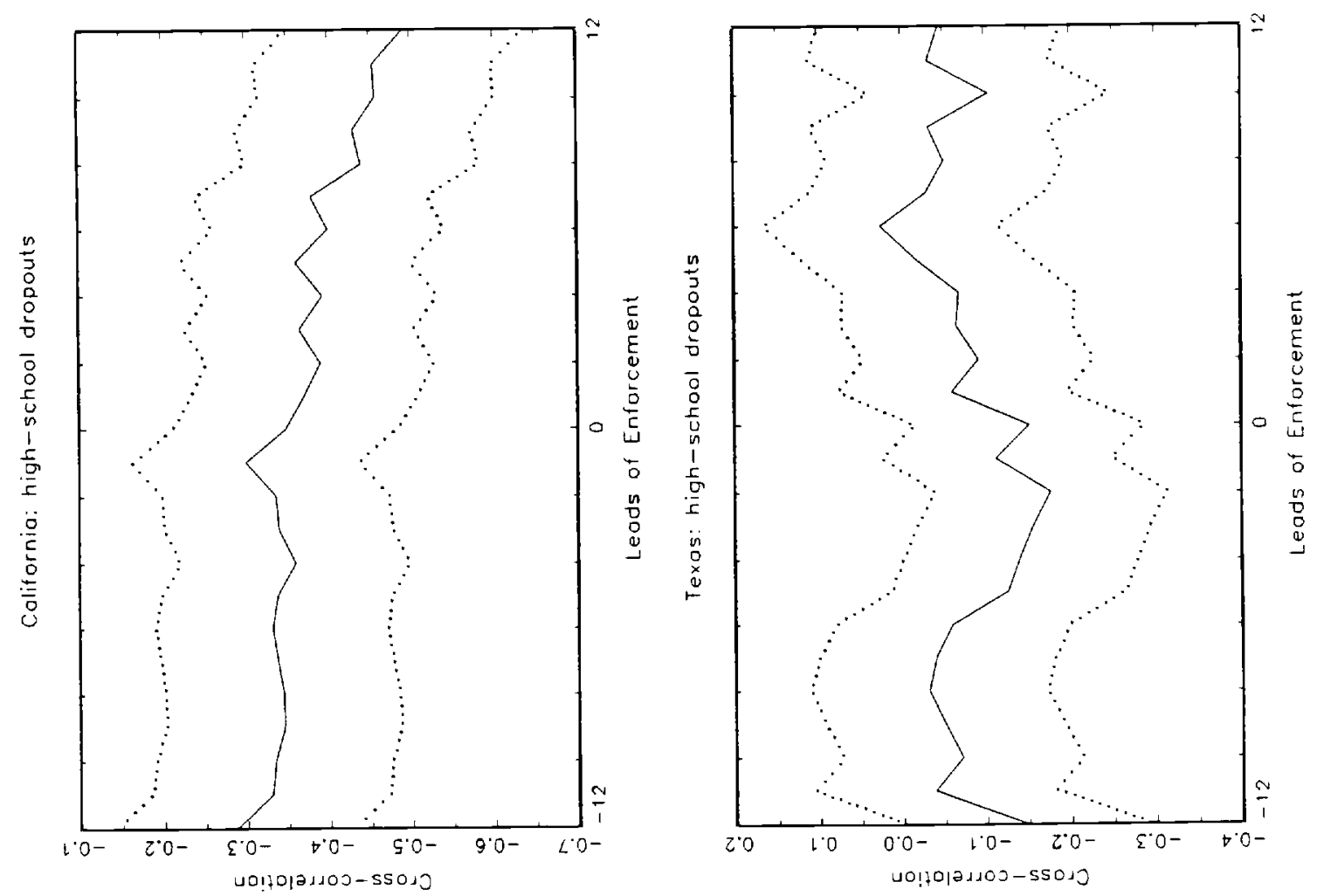

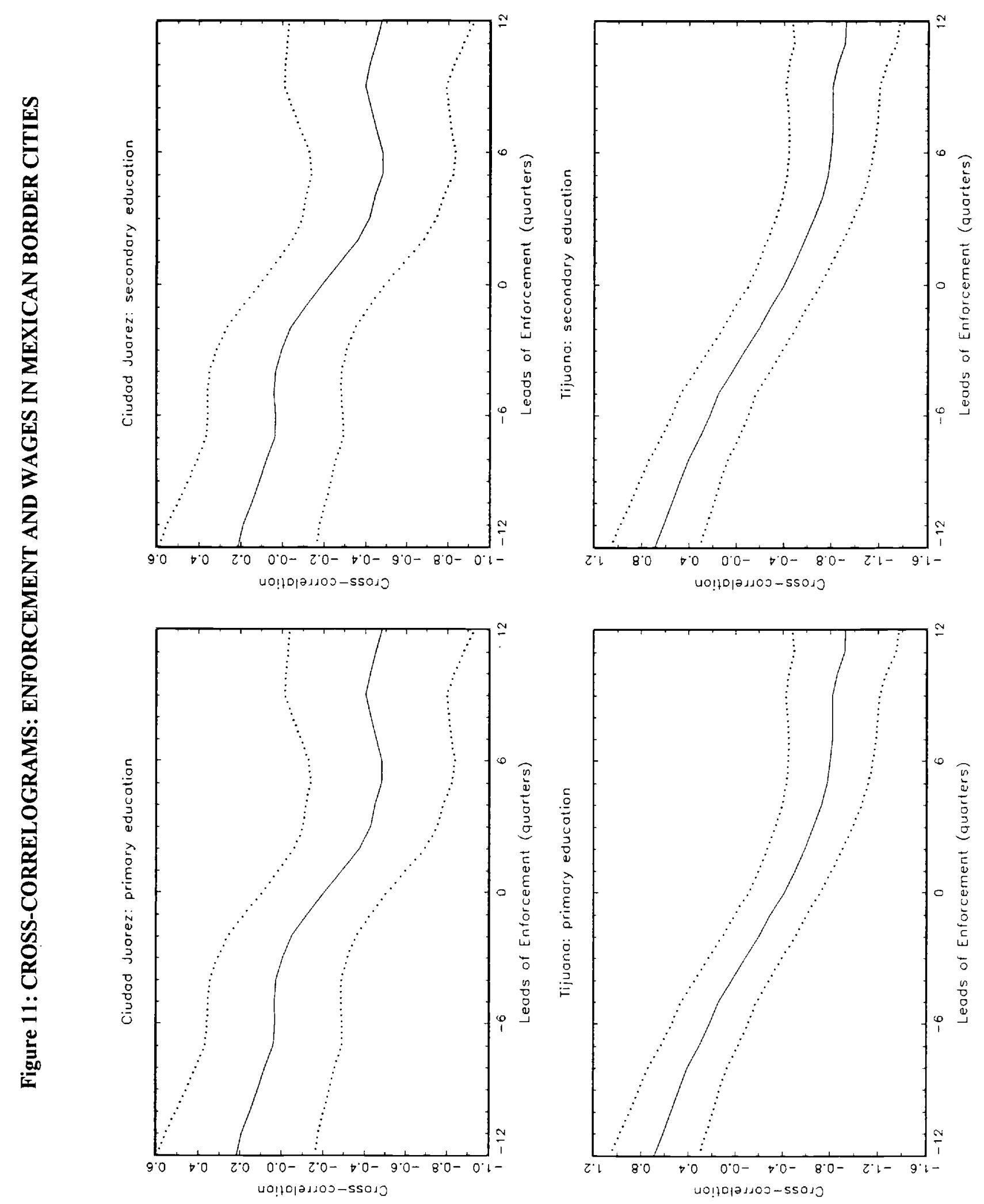